\title{
Trypillia Megasites in Context: Independent Urban Development in Chalcolithic Eastern Europe
}

\author{
Bisserka Gaydarska, Marco Nebbia \& John Chapman
}

The Trypillia megasites of the Ukrainian forest steppe formed the largest fourthmillennium BC sites in Eurasia and possibly the world. Discovered in the 1960s, the megasites have so far resisted all attempts at an understanding of their social structure and dynamics. Multi-disciplinary investigations of the Nebelivka megasite by an Anglo-Ukrainian research project brought a focus on three research questions: (1) what was the essence of megasite lifeways? (2) can we call the megasites early cities? and (3) what were their origins? The first question is approached through a summary of Project findings on Nebelivka and the subsequent modelling of three different scenarios for what transpired to be a different kind of site from our expectations. The second question uses a relational approach to urbanism to show that megasites were so different from other coeval settlements that they could justifiably be termed 'cities'. The third question turns to the origins of sites that were indeed larger and earlier than the supposed first cities of Mesopotamia and whose development indicates that there were at least two pathways to early urbanism in Eurasia.

\section{Introduction}

'The concept of "city" is notoriously hard to define.' This is the opening statement of Childe's $(1950,3)$ seminal article 'The urban revolution'. Almost 70 years later, this task has become even harder, with urbanism attested in a far wider range of environments, cultural trajectories and material forms than were known to Childe. Yet in western Asia and Europe, the traditional supremacy of Uruk urbanism-earlier than the first European city by two millennia-has remained intact and untroubled by global difference. While Minoan statehood may be dated to 2400 BC (Parkinson \& Galaty 2007, 118), the Late Minoan city of Knossos-at 100 ha the largest settlement on Crete (Morris 2005) — dates to the mid-second millennium $\mathrm{BC}$, showing that states may have developed without cities. Later still, classic examples of European cities co-emerged with states in the first millennium $\mathrm{BC}$ in Greece, Etruria and Rome (Morris 2005; Robinson 2014), while large, low-density, temperate European Iron Age oppida have an ambiguous relationship to urbanism (Moore 2017). This narrative enshrines the powerful tradition of equating urbanism with political and economic centralization (Yoffee 2015), which we dispute.

The second, empirical problem with this narrative is its exclusion of the largest sites in fourthmillennium $\mathrm{BC}$ Eurasia, if not the world-the Trypillia Chalcolithic megasites of the Ukrainian forest-steppe-and this despite a vigorous discussion of urban and non-urban status conducted largely in Russian and Ukrainian since the 1970s (KorvinPiotrovskiy 2003; Masson 1990; Shmaglij 2001; summarized in Supplementary Materials 1, online). Ignoring Fletcher's (1995) recognition of megasites as the only exception to his global rule of settlement constraints, most authors even today consider megasites as 'large villages' (see chapters in Müller et al. 2016b), with none of the core traits of Childean urbanism and no urban legacy (for an exception, 
see Wengrow 2015). However, advancing a relational approach rather than a Childean check-list compilation provides a new perspective on the urban debate.

In this article, we use the results of an AHRCfunded research project (2012-16) ${ }^{1}$ (Table 1) to investigate the question of European urbanism on the North Pontic forest-steppe through the multidisciplinary study of a single Trypillia megasiteNebelivka (Novoarhangelsk region, Kirovograd County) - in its wider landscape and cultural context (Fig. 1). The Trypillia-Cucuteni network (Russian Tripolye; hereafter ' $\mathrm{CT}$ ') covers over two millennia and three modern states-Romania, Moldova and Ukraine (Fig. 2). Unlike the Cucuteni part of the CT network, found in eastern Romania and Moldova, and which displayed a strong tendency to settlement dispersion in the late fifth millennium BC (Popovici 2000), the Trypillia part contained megasites defined as settlements of 100 ha or larger from 4100 to 3400 вс.

There are three research questions which are of primary concern: origins, megasite lifeways and urban status. We address these questions in a different order, ${ }^{2}$ since consideration of both urban status and megasite origins must be grounded in an interpretation of megasite lifeways that is radically different from the standard view of megasites as long-term permanently occupied settlements with tens of thousands of residents living in thousands of coevally used houses at the same time (Müller et al. 2016a).

The first question focuses on megasite lifewaysthe essence of what a megasite was and how it came to function in a large-scale landscape. It is here that the most dramatic changes in interpretation have emerged in the last decade. The traditional narrative has relied on the planned layout of megasites and the large number of solid, permanent houses, which in most accounts were coevally occupied, as proxies for long-term all-year-round occupation for thousands of people (e.g. Kruts 1989). Our research has managed to deconstruct this approach (Chapman 2017), leading to the modelling of three different scenarios for Nebelivka. While the social underpinning of two of the models rests on the seasonal patterning of social life, the third model relies on a broadly heterarchical social pact supporting permanent dwelling.

The second question confronts the urban status of Trypillia megasites, using a relational approach in which lifeways on a typical, small Trypillia site are compared and contrasted with what would have happened on a megasite. The results show that there is a strong case for calling Trypillia megasites 'cities' in their forest steppe context.
Table 1. Summary of Project activities. $\left(^{*}=\right.$ estimated value.)

\begin{tabular}{|c|c|}
\hline $\begin{array}{l}\text { Number of } \\
\text { units }\end{array}$ & Activity unit \\
\hline 6 & Years of fieldwork and excavation \\
\hline 1 & $\begin{array}{l}\text { Geographic zone (Northern tributaries of } \\
\text { Southern Bug) }\end{array}$ \\
\hline 14 & Field activities \\
\hline 7 & Field seasons \\
\hline 137 & Participants \\
\hline 286 & Ha of geophysical investigation \\
\hline 1445 & No. of houses identified \\
\hline $850^{*}$ & No. of pits identified \\
\hline 24 & No. of assembly houses identified \\
\hline 160 & No. of geophysical anomalies cored \\
\hline 10 (2619 sq. m) & Area excavations (area excavated) \\
\hline 88 (225 sq. m) & Test-pit excavations (area excavated) \\
\hline $86 / 25$ & AMS dates/radiocarbon dates \\
\hline 6 & Units tested with soil micromorphology \\
\hline 25 & On-site soil investigations \\
\hline 39 & Transect soil cores \\
\hline 75 & $\begin{array}{l}\text { Ha surveyed with intensive systematic } \\
\text { fieldwalking }\end{array}$ \\
\hline $178(574)$ & $\begin{array}{l}\text { Sq. km of linear valley walked by extensive } \\
\text { survey (ha. fieldwalked) }\end{array}$ \\
\hline 4 & No. of sites with intra-site gridded collection \\
\hline 34 & Surface concentrations documented \\
\hline 800 & Burial mounds registered \\
\hline 5 & Sediment cores collected \\
\hline 1 & Full multi-proxy analysis of sediment core \\
\hline 15 & Units investigated in megasite hinterland \\
\hline 2 & No. of experimental houses built \\
\hline 1 & No. of experimental houses burnt \\
\hline 1 & No. of excavations of burnt house remains \\
\hline 2 & No. of building experiments, Durham \\
\hline $37,000^{*}$ & No. of sherds excavated \\
\hline $21,300(504 \mathrm{~kg})$ & No. (weight) of sherds fully studied \\
\hline 6316 & No. of animal bones excavated \\
\hline 150 & No. of chipped stone studied \\
\hline $85^{*}$ & No. of ground stone tools \\
\hline $291(143)$ & No. of special finds (figurines) \\
\hline 5248 & No. of digital images in ADS Project Archive \\
\hline 394 & No. of documents in ADS Project Archive \\
\hline
\end{tabular}

The origins of the Trypillia megasites have been regularly discussed over the last 30 years, with the military/strategic response to internal and/or external threat generally being considered adequate to explain this settlement hyper-nucleation (Dergachev 


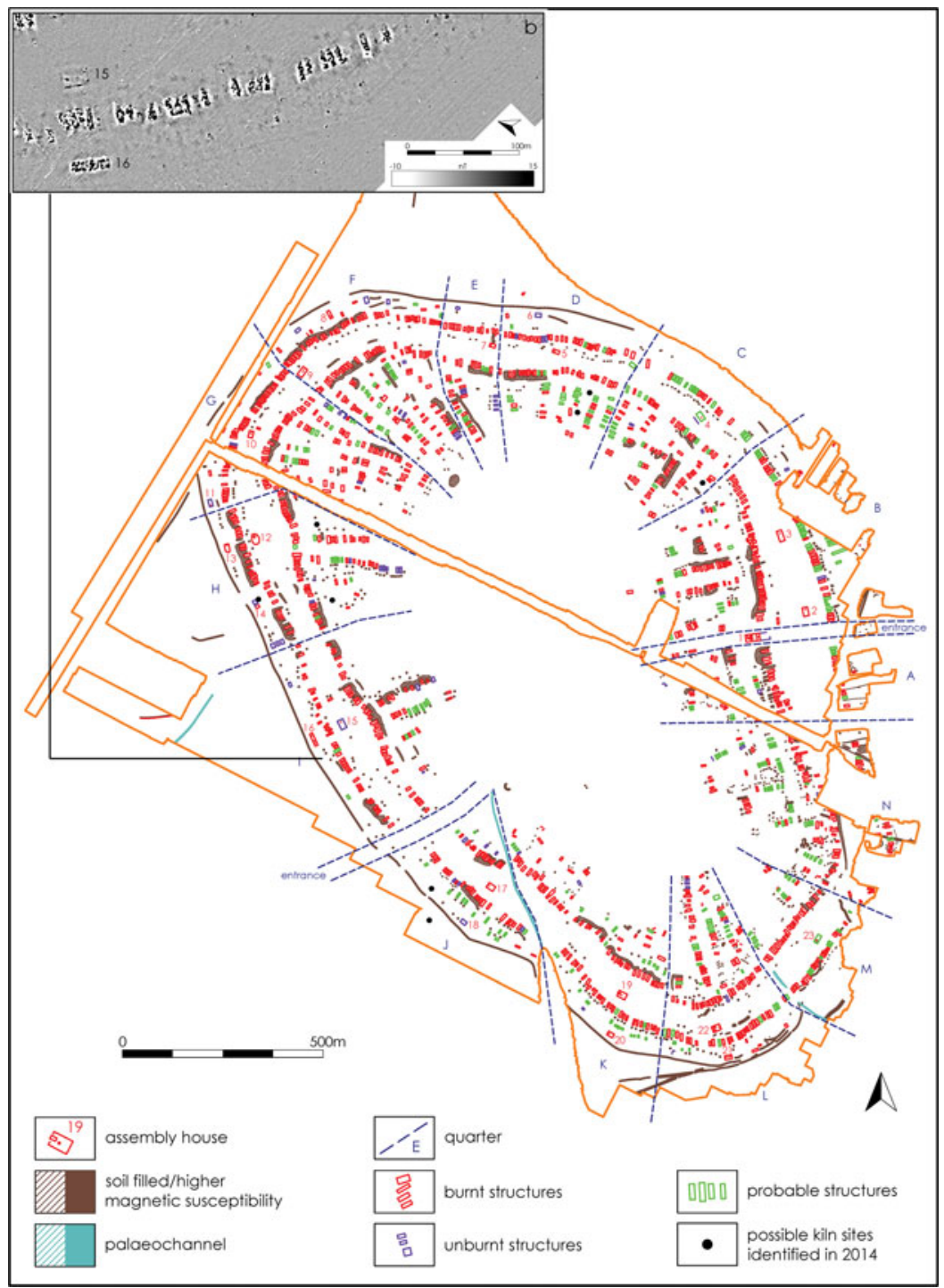

Figure 1. Magnetometer plan of the Nebelivka megasite, with Quarter boundaries defined by criteria discussed in Chapman \& Gaydarska (2016). (Y. Beadnell, based on data from D. Hale.) Inset (b) Nebelivka Neighbourhood with numbered Assembly Houses. (J. Watson.)

2002; Kruts 1989; Zbenovich 1990; but see Manzura 2005). Our approach takes a different starting-point of how Trypillia communities used to living in settlements of 20-40 ha could have imagined the possibility of creating a site 10 to 20 times as large. But before we turn to the research questions, it is important to gain some perspectives on how we conceptualized megasites and developed a feel for the contexts in which megasite archaeology has developed.

\section{Conceptualizing/contextualizing megasites}

Studying megasites and Balkan Neolithic tells may be mapped onto the difference between the Orient
Express and a commuter train from Bushey to Euston: it is hard to comprehend the vastness of the former, while not denying the intrinsic interest of the latter. It is not only the megasites that are vast - it is also their landscapes and the time-space dimensions of the CT network. The rolling forest steppe-covered loess landscapes carry on for thousands of kilometres, while, at a local level, a single Soviet-era field in central Ukraine can be larger than an entire English parish. Moreover, the CT network lasted longer and covered a wider area than any other central and eastern European networkfrom 5000 to 2800 BC and more than 250,000 sq. km (Monah \& Monah 1997; Videiko 2013) (Fig. 2). By 
(a)
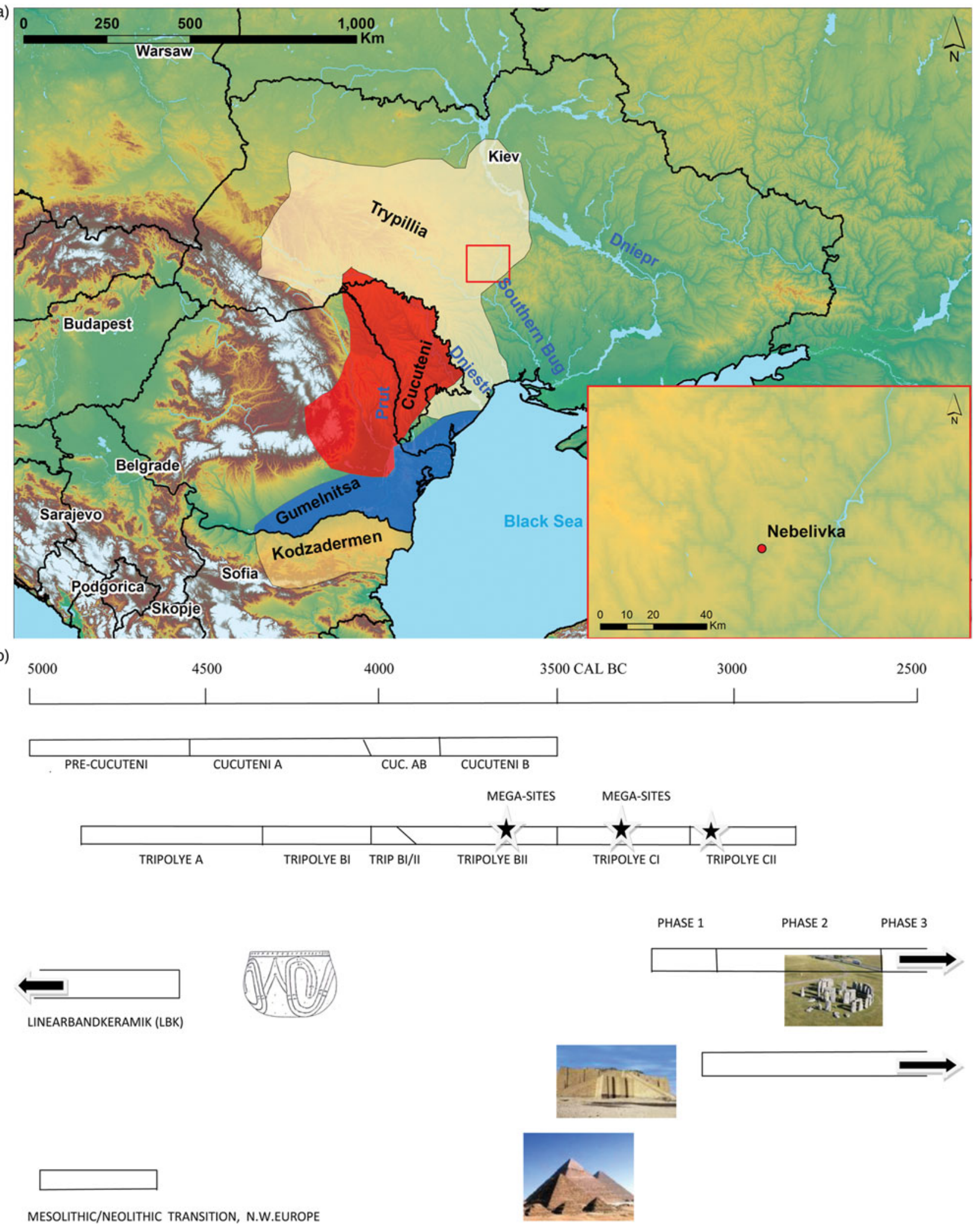

Figure 2. (a) Distribution map of Climax Copper Age groups, including the Cucuteni-Trypillia group (M. Nebbia); (b) timeline of the Cucuteni-Trypillia group, showing the timeline of the Trypillia megasites relative to other major world monuments (Y. Beadnell). 
comparison, the Vădastra network in modern Romania lasted 200 years and covered 6000 sq. km, while the Veselinovo network in Bulgaria lasted 300 years and covered 60,000 sq. km (data from Chapman in prep.). Ukrainian specialists have claimed the existence of more than 60 local 'groups' within the Trypillia network alone (Shukurov \& Videiko 2017, 3). The scale of these phenomena is not only theoretically challenging but also poses many methodological problems of how to investigate such sites/landscapes/cultural groups (Table 1). ${ }^{3}$

The first question of scale concerns the way that clearly similar though varying material culture was replicated over such distances and reproduced over $80+$ generations. We have found Lacan (1988) and Žižek's (2012, 86-92) concept of the 'Big Other' stimulating in this respect. Alongside and 'above' the daily household practices which characterized the habitus - what Bloch (2008) has termed 'transactional social practice' (see below) - the Big Other played an overarching, integrative role as a virtual symbolic order (in Bloch's terms, a 'transcendental entity') that existed only through its subjects believing in it-something which was sufficiently general and significant to attract the support of most members of society but, at the same time, sufficiently ambiguous to allow the kinds of localized alternative interpretations ('transactional practices', according to Bloch) that avoid constant schismatic behaviour. These localized interpretations became materialized in three principal forms which were all central to CT cultural identity: different types of painted pottery, different kinds of figurines and houses of different shapes and sizes (Chapman \& Gaydarska 2018) (Fig. 3). All three forms were concentrated in the domestic domain, where the mortuary domain and hoarding practices were virtually invisible. ${ }^{4}$ While for typological 'splitters', the variability in these three forms permitted the etic differentiation of over 60 local groups, a CT person would have emically recognized a vessel as 'theirs' in a pottery assemblage from a settlement $800 \mathrm{~km}$ away from their home. Diachronic studies of CT figurine usage shows continuity in discard practices over the entire CT timespan (Gaydarska 2019c). The Big Other was fundamental in the growth and expansion of the CT network, transcending face-to-face contact and local social networks to enable continuities of practice and identities across vast distances. But the Big Other leads us to an important question concerning the role of imagination in the CT network.

In Imagined Communities, Anderson's influential study of the anomaly of modern nationalism, the author $(1991,4)$ reminds us that all communities larger than a single village were 'imagined communities', because separate communities have, by definition, never lived together with a second group. Bloch (2008) has recently expanded the use of the term 'imagined communities' to beyond the political framework, suggesting that the transcendental social consists of essentialized groups which exist because they are 'imagined', whether as descent groups or religious groupings. There are therefore three different levels at which imagined communities have taken root in the CT network: at the level of the megasite, at the level of the descent group whose members spanned two or more settlements, and at the far larger scale of the 'Big Other' itself. The Big Other can be conceived in Bloch's terms as 'a totalising transcendental representation without its political foundation' $(2008,2060)$.

For the imagined community of megasites, we suggest that the first step of the integration of people beyond their normal, face-to-face groups had been taken through the evolution of the Big Other as much as the development of transcendent local and regional descent groups. But local Trypillia settlement groups still required a vision of how diverse communities could live together to derive benefits from the new settlement form that were considered greater than the difficulties this linkage may have brought. After all, there is a long tradition, supported by Childe (1958), of actualizing the advantages of autarky - living in independent, face-to-face communities-which put a long-term brake on the scale of settlement nucleation in prehistoric Europe.

It is easy to forget the unprecedented nature of Trypillia megasites, which have created immense problems of explanation and understanding, but first of all, problems of imagination. On the Eurasian continent of the fifth-fourth millennia $\mathrm{BC}$, the Trypillia megasites were unique in size and scale. There was nothing anywhere else on the planet, at $4200 \mathrm{BC}$, to compare with the Phase BI megasite of Vesely Kut, covering an area of 150 ha-no analogies from which to derive this extraordinary place. In our discussion of how the earliest megasites were imagined, we shall return to the issues of their cultural background, the changes which stimulated their growth and their advantages and disadvantages.

In the theoretically divided terrain of the last three decades, one of the areas in which postprocessualists, interpretative archaeologists and those of the ontological turn have made least impact has been urbanism. With a handful of exceptions (e.g. Christopherson 2015; M.L. Smith 2003), research into urban developments has been the domain of the processualists, who have focused on wide-ranging 


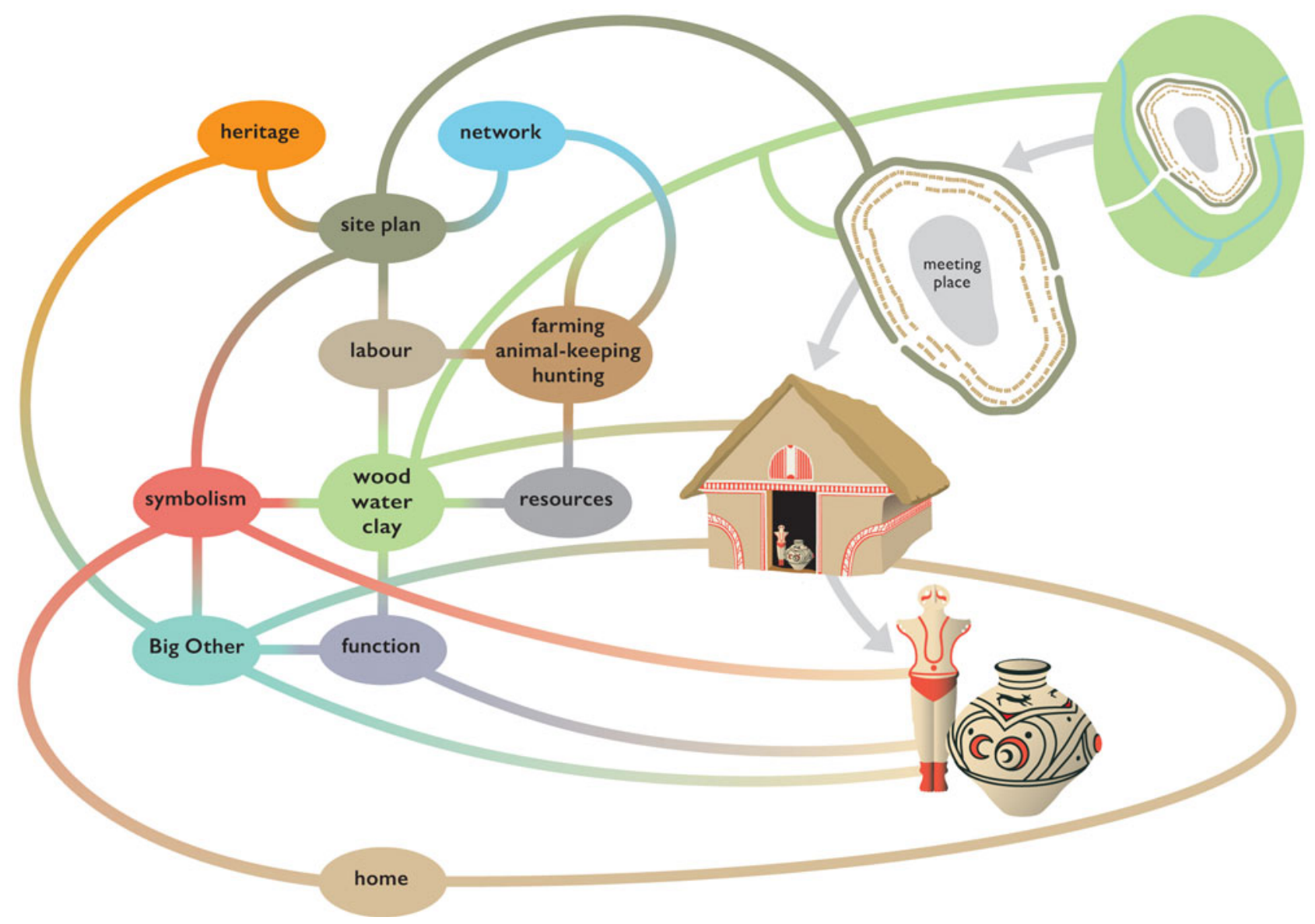

Figure 3. The Trypillia Big Other, showing the most salient relationships between the constituent parts of the Big Other (houses, pottery and figurines) to other aspects of Trypillia lifeways. (C. Unwin.)

processes of change and often grand narratives to account for what was clearly a critical step in the human past (Flannery \& Marcus 2012; Marcus \& Sabloff 2008). One of the problems that interpretative archaeologists have faced is the scale of the processes, which tend to be beyond their comfort zone. As previously discussed, the similarities of the scale of CT settlement and those of early urban networks make the interpretation of $\mathrm{CT}$ just as problematic as other early cities. This means that conceptualizing $\mathrm{CT}$ in terms of the Big Other and 'imagined communities' does not make for ready linkages to urban origins. The route that we have taken remains, however, true to post-1980s contextual and relational approaches.

The term 'urban' is a modern analytical construct, largely used as an essentialist concept, but more recently used to encompass very different phenomena worldwide. This contradictory usage stems from the tension between the desirability of a single definition and the diversity of cases that make this impossible. Historical, anthropological and epigraphic sources informing us about the emic views of cities reveal not only linguistic differences but, more significantly, very different understandings of the phenomenon. Thus, the introduction of an etic category such as 'urban' seems reasonable to reconcile these cross-cultural differences, allowing comparisons of human development. It is easy to overlook this feature of the term 'urban' due to its Latin origin, its implied Eurocentrism and the unfortunate interchangeability of the terms 'urban' and 'city'.

Defining 'urban' might be helpful in distinguishing between 'urban' and 'non-urban' lifeways, were it not for the static and descriptive aspects of any definition, especially in a constantly expanding field. By contrast, analytical constructs are more flexible and can be regularly updated. In this paper, we have chosen not to produce a definition of 'urban' since we believe that such an operation has, in the past, done more harm than good through the 
essentialization of selected criteria. Instead, we rely on 'urban' as an analytical construct whose constitutive points are relational rather than fixed. In this sense, the term 'megasite' resembles the Chinese character for 'city' or the Greek word 'polis'.

Looking for cities in context rather than as examples of essentialized universalities is not a novel concept (Gaydarska 2017), but it has been continuously undermined by what has become the traditional view of urbanism. As early as his 1938 discussion of the number and density of urban communities, the prominent sociologist Louis Wirth noted: 'But these criteria must be seen as relative to the general cultural context in which cities arise and exist and are sociologically relevant only so far as they operate as conditioning factors in social life' (Wirth 1938, 6). However, another quotation from his seminal work has largely eclipsed his contextual insight in urban research, namely the definition of the city as a 'relatively large, dense and permanent settlement of socially heterogeneous individuals' (Wirth 1938, 8). More than 60 years later, it was the American archaeologist George Cowgill $(2004,526)$ who advocated a more flexible approach that looks for 'a city', rather than 'the city', and approaches urban 'variables' in a novel manner. His suggestion is 'it is useful to think of urbanism as a cluster of variables that can be measured (if only roughly) on ordinal or interval scales, rather than as a discrete category' (Cowgill 2004, 527). Building on this study, yet a third influential figure, the American archaeologist Michael Smith (2016, 159 \& table 10.1), has developed an approach to measuring 'citiness' in a non-constraining way. Yet these approaches have as yet had little effect on the mainstream notion of what is 'urban'. What we have attempted is a fully worked-out example of a relational comparison between a megasite and a small Trypillia site (Gaydarska 2019b, section 6.3).

In summary, the major and complex issue for any project seeking to confront Trypillia megasites is the issue of scale. Just as Trypillia megasites posed a problem of how fifth-millennium communities could imagine a site $10-20$ times the size of what they habitually built and occupied, the question of scale confronts each project with logistical, methodological and sampling issues of how to investigate such massive sites, such huge landscapes. A further question of scale also applies to one of the key Project research questions. One distinctive trend in post-1980s archaeology has been the focus on ever more detailed questions, based on ever more localized data sets-a trend that has prevented many interpretative archaeologists from making a creative contribution to research into urban origins and development. Just as transcending the limitations of face-to-face contacts and local networks was essential to the development of megasites, so our research project has sought to transcend issues of scale in our theoretical approach, relying on a relational and contextual approach to early cities which remains true to post-processual and interpretative principles. With these scalar issues in mind, it is time to turn to the three principal research questions which the Project addressed, beginning with our re-interpretation of Trypillia megasite lifeways.

\section{Megasite lifeways}

One of the most salient questions in megasite archaeology concerns what was happening on these massive sites-not just in very general terms (cattle husbandry, pit-digging, house-burning), but in integrated detail. Here, we turn to some of the key Project findings which, in our view, provide an alternative view of megasite functions to those found in most recent accounts (Müller et al. 2016b; Videiko 2013).

The introduction of modern geophysical techniques of investigation has had a dramatic impact on Trypillia research, with pedestrian fluxgate gradiometry utilized at Nebelivka (Chapman et al. 2014b) and vehicular caesium magnetometry at Taljanki, Majdanetske, Dobrovody and Apolianka (Rassmann et al. 2016). The Project has produced the only complete megasite plan so far, with a site area of 238 ha inside a shallow perimeter ditch (Fig. 1). All of the principal planning elements recognized in the first stage of megasite research (1970s80s) have been confirmed in this second stage: the multiple concentric house circuits separated by large spaces, the inner radial streets leading to an open inner space, and the high frequencies of burnt houses and lower totals of unburnt/poorly burnt structures. In addition, recent geophysical research has identified several new classes of anomalies: (unburnt/poorly burnt houses, pits of differing sizes, large structures interpreted as public buildings, industrial features-kilns or cooking facilities, perimeter ditches, garden areas, palaeochannels and pathways), as well as new combinations of elements (Neighbourhoods, Squares and pit lines/groups). These new elements and combinations enabled the production of a much more dynamic narrative of megasites than was previously possible (Chapman et al. 2014c; Gaydarska 2019a).

The total of 86 AMS dates would, in most circumstances, have enabled the Bayesian modelling 

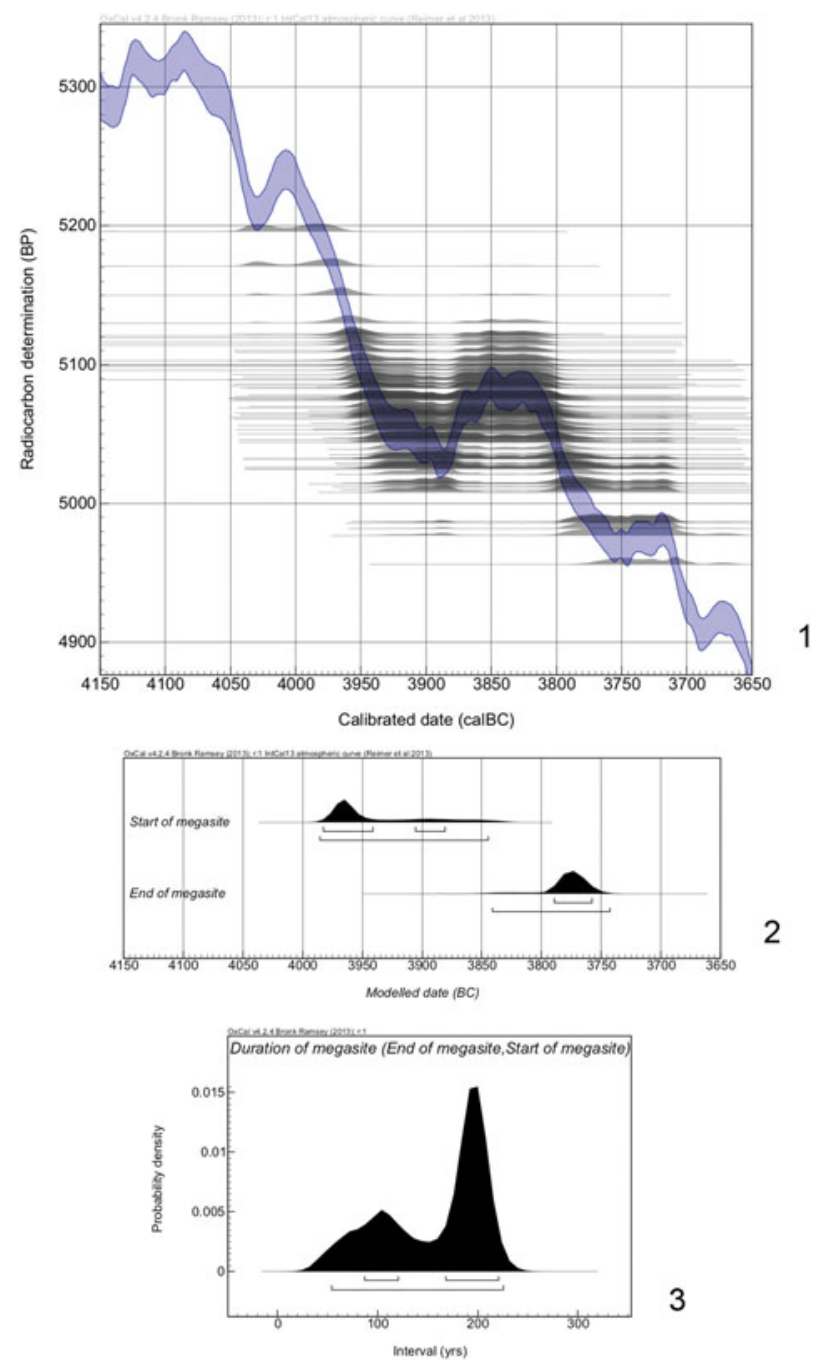

3

Figure 4. Bayesian model of start and end dates for Nebelivka megasite occupation. (A. Millard.)

of a robust internal chronology for the megasite, informing us on the relative start and end dates of the inner and outer circuits, the Squares and the inner radial streets. Unfortunately, the coincidence of dates with a wiggle in the calibration curve prevents an adequate internal sequencing, leaving us with the most probable dating for the overall occupation of 200 years (3970-3770 BC) (Fig. 4). This dating provides a secure chronology for part of Phase BII of the Trypillia group. Modelling of the number of houses and the length of occupation suggests that between a third and a sixth of all houses were occupied simultaneously (Supplementary Materials 7, online).

The centre of the megasite plan comprises a 65 ha open area with no evidence for building or deposition-an area that could have contained almost any previous Trypillia site (Fig. 1). Monica Smith (2008) has demonstrated how open areas were active participants in the social space of complex sites, carefully managed and often with seasonal changes in function. The significance of the inner open area for major megasite ceremonials and regional-scale meetings has been overlooked in previous research.

At first sight, the regularity of the megasite plan suggests a hierarchical social order, with the power to impose a site-wide plan and control housebuilding in a regular layout (Rassmann et al. 2016). But the new geophysical investigations show that this regularity is deceptive, with 18 different forms of variability in plan detail (Table 2). This heterogeneity was seen in major plan elements, such as the distance between the outer and inner house circuits or the length of uninterrupted perimeter ditch sections, as well as minor planning elements, such as the presence and alignment of kinks in house circuits or the presence/absence of blocking streets cutting off radial streets from the inner open area. This high level of variability is a strong indicator that the Nebelivka plan was created from the bottom up rather than imposed hierarchically from the top down; indeed, there was so much planning heterogeneity that the opposite problem of social integration may have been more important to megasite survival.

\section{Households, Neighbourhoods and Quarters}

The improved resolution of Nebelivka's geophysical plan enabled a more structured interpretation of social space, with two additional nested levels between the levels of the house and the entire site - the Neighbourhood and the Quarter. At the smallest scale, houses made a statement about the whole Trypillia landscape, with construction materials collected from all parts of the landscape. Using information from our experimental house-building programme, the average $15 \times 5 \mathrm{~m}$ house, mostly two-storeyed, would have taken 10-12 people one month to construct, with the largest houses taking twice as many person-days (Supplementary Materials SM2, Tables 1 \& 2, online). Two-thirds of Nebelivka houses had been deliberately burnt to a high temperature, with the remainder weakly burnt or unburnt. The experimental finding that five to ten times more timber was required to burn a house as to build it confirms the notion of deliberate burning and has major implications for landscape impact. The burnt remains of about 10 per cent of the houses formed a low mound (Fig. 5), visible on the surface, unlike the burnt houses on a Balkan 
Table 2. Nebelivka megasite: types of planning and architectural variability. $(I C=$ Inner Circuit; OC = Outer Circuit; IRS = Inner Radial Street; $\mathrm{NBH}=$ neighbourhood.) (J. Chapman.)

\begin{tabular}{|c|c|}
\hline Type of variability & Variations observed \\
\hline length of causeways in the perimeter ditch & $20-55 \mathrm{~m}$ \\
\hline length of uninterrupted ditch lengths between causeways & $32-640-720 \mathrm{~m}$ \\
\hline $\begin{array}{l}\text { width of the outer open space between the perimeter ditch and the } \\
\text { Outer Circuit }\end{array}$ & $40-70 \mathrm{~m}$ \\
\hline $\begin{array}{l}\text { presence or absence of dwellings, or even Neighbourhoods, in the outer } \\
\text { open space }\end{array}$ & $\begin{array}{l}\text { Outside OC: total of 78, from } 0 \text { (Quarters C, M, N) to } 16 \\
\text { (Quarter K) }\end{array}$ \\
\hline $\begin{array}{l}\text { presence or absence of pits inside or outside houses in either Circuit or } \\
\text { Inner Radial Street and the relationship of the pits to those houses }\end{array}$ & $\begin{array}{l}\text { OC NBH } 76 \text { \& 102: no pits } \\
\text { OC NBH 9 \& 10: pits outside houses } \\
\text { OC NBH } 47 \text { \& 48: pits inside some houses } \\
\text { OC NBH 62: pits inside all houses } \\
\text { IC NBH } 26 \text { \& 34: no pits } \\
\text { IC NBH 118: pits outside some houses } \\
\text { IC NBH } 3 \text { \& 4: pits inside houses } \\
\text { IRS } 20 \text { \& 28: no pits } \\
\text { IRS } 42 \text { \& 83: pits on one side } \\
\text { IRS } 95 \text { \& 96: irregular location of pits vis-à-vis houses }\end{array}$ \\
\hline $\begin{array}{l}\text { presence or absence of an Assembly House in the outer or middle open } \\
\text { space }\end{array}$ & 9 outside the outer circuit; 14 between the circuits \\
\hline number of houses in a Neighbourhood (excluding Squares) & $3-22$ \\
\hline Number of houses in Squares & $15-27$ \\
\hline $\begin{array}{l}\text { alignment or otherwise of gaps between Neighbourhoods and } \\
\text { causeways in the perimeter ditch and between Neighbourhoods in both } \\
\text { Circuits }\end{array}$ & $\begin{array}{l}\text { No alignment: Gap 2, Quarter F; Gap 6, Quarter H; Gap 7, } \\
\text { Quarter I; Gap 10, Quarter J; Gaps } 12 \text { \& 13, Quarter L } \\
\text { Alignment: Gap 8, West entrance; Gap 14, Quarter L }\end{array}$ \\
\hline presence or absence of kinks in Inner or Outer Circuits & $\begin{array}{l}\text { IC: NBHs } 64 \text { \& 79/border of Quarters G \& H; NBHs } 112 \text { \& } \\
\text { 117A/border of Quarters K \& L; NBHs } 134 \text { \& 135/Quarter N } \\
\text { OC: NBHs } 48 \text { \& 58/border of Quarters F \& G; NBHs } 75 \text { \& 76/ } \\
\text { Quarter H }\end{array}$ \\
\hline alignment or otherwise of kinks in both Circuits & $\begin{array}{l}\text { NBHs } 104 \& 110 \text { (IC) + } 103 \text { \& } 106 \text { (OC): Palaeochannel at } \\
\text { border of Quarters J \& K }\end{array}$ \\
\hline width of the middle open space between the two Circuits & $60-160 \mathrm{~m}$ \\
\hline Length of offsets (kinks) & $25-40 \mathrm{~m}$ \\
\hline presence or absence of Inner Radial Streets inside the Inner Circuit & $\begin{array}{l}\text { Highest in Quarters E-H, lowest in Quarters I-K; } \\
52 \text { RS: houses from } 2 \text { to } 26\end{array}$ \\
\hline presence of Squares in the IIC & In Quarters B, C and N \\
\hline $\begin{array}{l}\text { presence or absence of blocking streets (streets cutting off the further } \\
\text { development of Inner Radial Streets) }\end{array}$ & $\begin{array}{l}\text { NBH 18, Quarter B } \\
\text { NBH 73, Quarter G } \\
\text { NBH 146, Quarter N }\end{array}$ \\
\hline number of Neighbourhoods in a Quarter & $6-16$ \\
\hline number of Assembly Houses in a Quarter & $\begin{array}{l}\text { A, C, E, M: } 1 \\
\text { B, D, F, G, I, J, K, L: } 2 \\
\text { H: } 3\end{array}$ \\
\hline
\end{tabular}

tell, which were usually levelled for the next building phase (Chapman \& Gaydarska 2019). Steady accumulations of these 'memory mounds' across the site turned Nebelivka from a dwelling site to a mixture of settlement and 'burnt house cemetery'.

The grouping of houses into Neighbourhoods provided a local context of living in neighbourly proximity, with most households no more than $30 \mathrm{~m}$ from each other. Neighbourhoods are defined by a minimum of three houses separated at each end of the group from the next house (Fig. 1/inset). While up to 27 houses were found in the total of 153 Neighbourhoods, over half comprised three to seven houses. Larger Neighbourhoods suggested longer durations or greater demographic growth. The experimental programme estimates (Supplementary Materials SM2, Tables 1 \& 2, online) show that seven houses of average size could have been built by 50 people in 40 days-perhaps by visitors to/residents at Nebelivka from a single home community. 


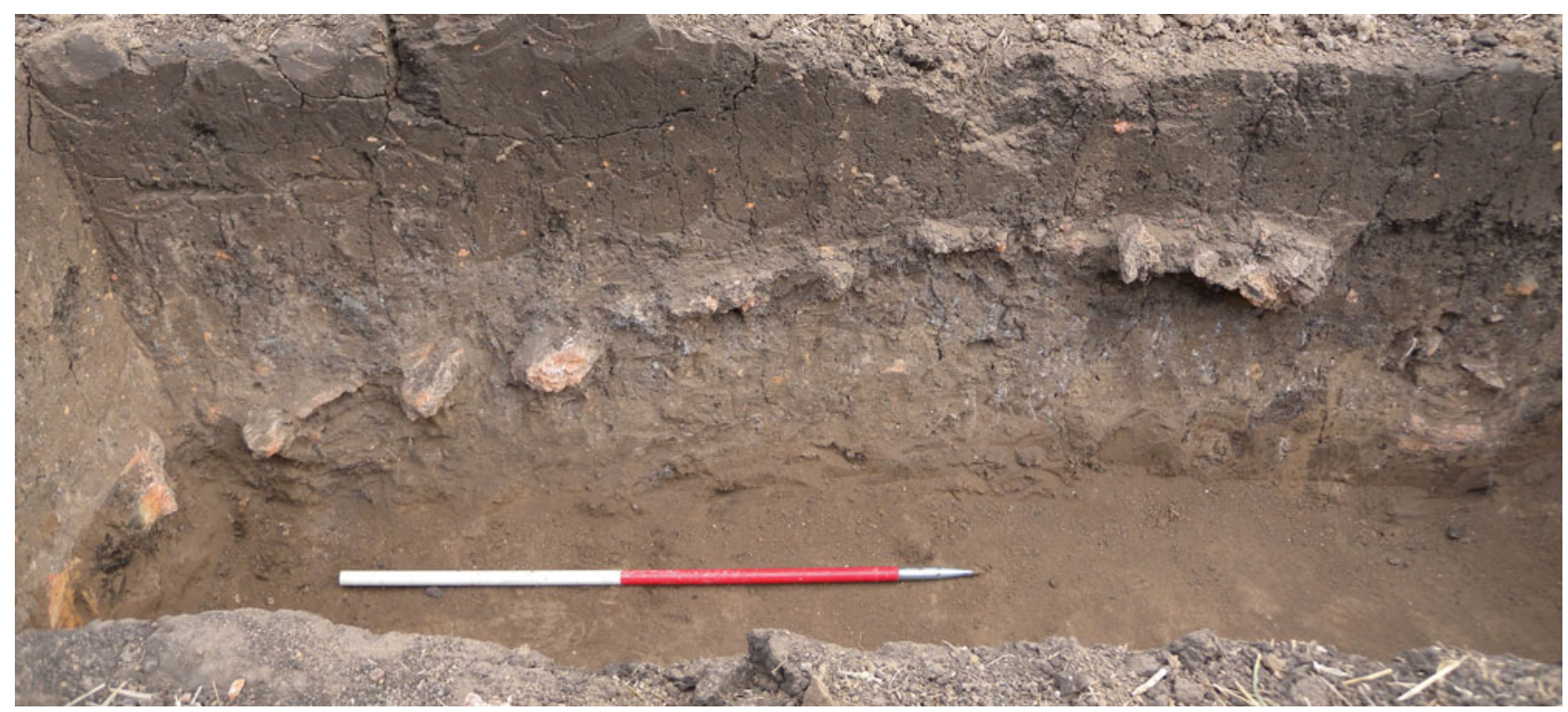

Figure 5. Mound of burnt house debris, Test Pit 22/4, Nebelivka, showing the formation of a 'memory mound'. (B. Gaydarska.)

Local dynamism was evident in most Neighbourhoods in two ways-the wide range of house sizes and the variety of house-burning treatments-some completely burnt, others weakly fired (Fig. 1). Neighbourhoods provided a focus for multiple local identities which contrasted with, and may have posed a threat to, an overall Nebelivka identity which was central to the long-term success of the megasite. These local Neighbourhood identities dampened inter-household scalar tensions without necessarily decreasing scalar stress between neighbourhoods. Such higher-level disputes may have been solved at the next level up-the Quarter.

The 14 Nebelivka Quarters have been defined using multiple criteria (Chapman \& Gaydarska 2016) (Fig. 1). Covering an areal range of 5-20 ha, Quarters represented a scalar change in size, perhaps five or ten times the size of Neighbourhoods, and were larger than the average small Trypillia site. Each Quarter differed from other Quarters in size, number and size of houses and Neighbourhoods, suggesting origins from a variety of outside communities from whom visitors to Nebelivka had been drawn. The moderate differences between Quarters revealed through GINI coefficent analysis (see Supplementary Materials 4, online, for details) may be compared with the findings of greater house size variability by Quarter (see Supplementary Materials 5, online, for details); only two Quarters showed high scores in both analyses, underlining the modest social differentiation at this level. Both
Neighbourhoods and Quarters helped to mitigate scalar stress (Johnson 1982) by a combination of living conditions at a local community scale and unprecedented opportunities for social interaction at a vast scale. However, despite variability in size and layout, a pioneering application of Visibility Graph Analysis using the software package Depthmap (see Supplementary Materials 3, online, for details) showed similar structuring of visibility and movement through space in all of the analysed Quarters (Fig. 6). This was particularly evident in the location of the public buildings termed 'Assembly Houses' in the most visually integrated and public zones of each Quarter. This finding indicates the tensions between an overall Nebelivka identity and the variability within Quarters highlighting a series of local identities.

\section{Artifact studies}

The Nebelivka excavations showed an archaeology of selective fragmentation and practices of episodic discard and deposition, as revealed through the taphonomic filter of the finds in structures and pits. While the discard of food refuse and lithic knapping debris indicated in situ practices, the majority of discarded and deposited remains do not provide a direct reflection of daily lives (a 'living assemblage'), but rather constitute a series of interventions which brought together a range of people in deliberate depositional practices, such as the unusual but not rare event of a house-burning performance. This means that the 


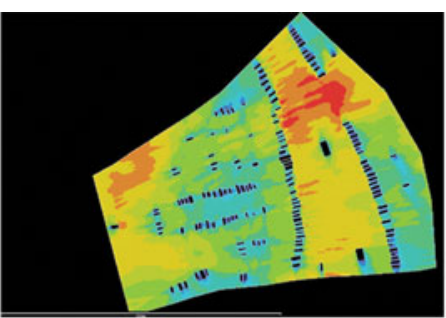

1

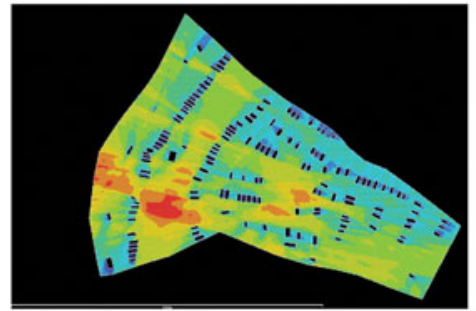

4

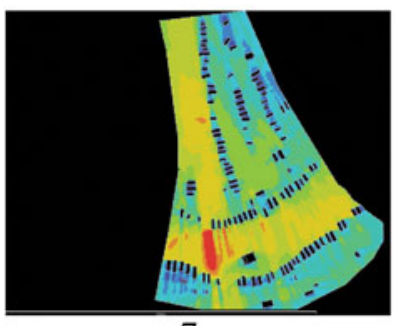

7

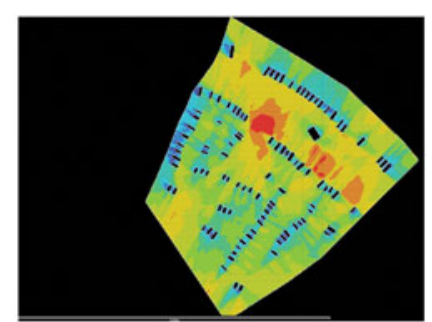

2

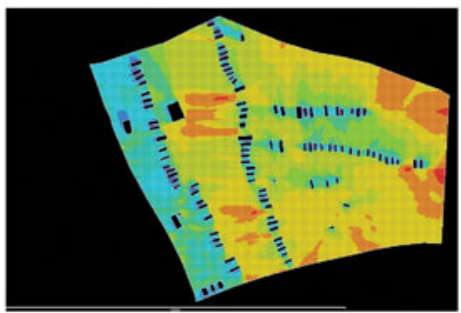

5

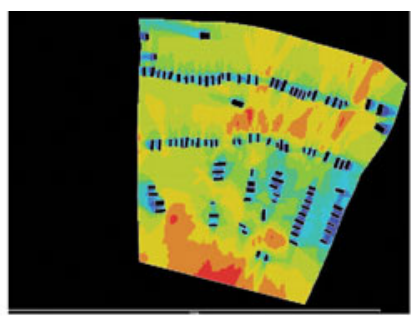

3

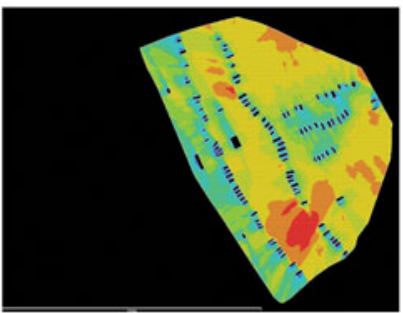

6

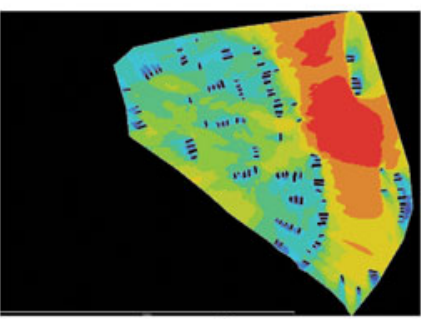

9

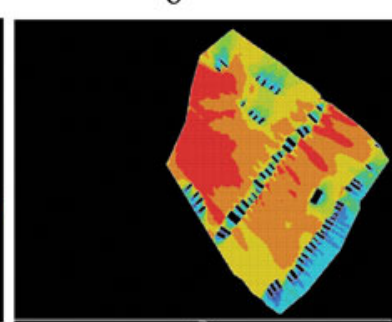

10

Figure 6. Visibility graph analysis: connectivity analysis of 10 Quarters: (1) B; (2) C; (3) D; (4) $G$; (5) $H$; (6) $I$; (7) $L$; (8) F; (9) N; (10) M. (B. Buchanan.)

deposited finds cannot be conceived as a direct reflection of, for example, household social differentiation, but rather in terms of contributions by different households to the 'house death assemblage', as a way of materializing inter-household relations.

Those maintenance activities which the Nebelivkans chose to exclude almost completely from their performances were food storage, plantfood preparation, cooking, the making of clothes and tool-making from bone, stone and metal. Special finds such as fired clay tokens and ornaments were also rarely deposited, although the overall density of figurine deposition matched that of small Trypillia sites (Gaydarska 2019c). A startling absence from burnt house assemblages was the functionally coherent pottery group indicating a 'living assemblage'. While specialized production can be related to the construction of Assembly Houses and widespread painted pottery production, we can also identify skilled production by what Timothy Taylor called 'limited interest groups' of builders, potters, flint-knappers, bone tool-makers and figurinemakers (for discussion of term, see Chapman \& Dolukhanov 1993).
The scale of depositional practices at Nebelivka ranged from the single event, such as an episode of placing fragments of two vessels in a pit fill, to the massive communal ceremony of the burning of the megastructure-the largest Assembly House at Nebelivka and, at $60.5 \times 18.3 \mathrm{~m}$, the largest Trypillia structure yet found (Chapman et al. 2014a) (Fig. 7). The megastructure deposition involved the placement of over $60 \mathrm{~kg}$ of pottery derived from at least 332 vessels-the majority for communal consumption-with variability in vessel fabric suggesting contributions from many households and Neighbourhoods. The most striking collective find was the group of 21 miniature vessels, with six vessels showing the first examples of graphite-painted decoration (Fig. 8/1) and a graphite wash ever found in the Trypillia group. One graphite-painted vessel was most probably an import from the Gumelniţa group in the Lower Danube valley (Fig. 8/3).

Small numbers of objects hint at ancestral relations with pre-megasite groups, such as the flint rhomboid point (Fig. 9/1), lunate (Fig. 9/2) and rare incised fine ware vessels (Fig. 8/3). Others still 


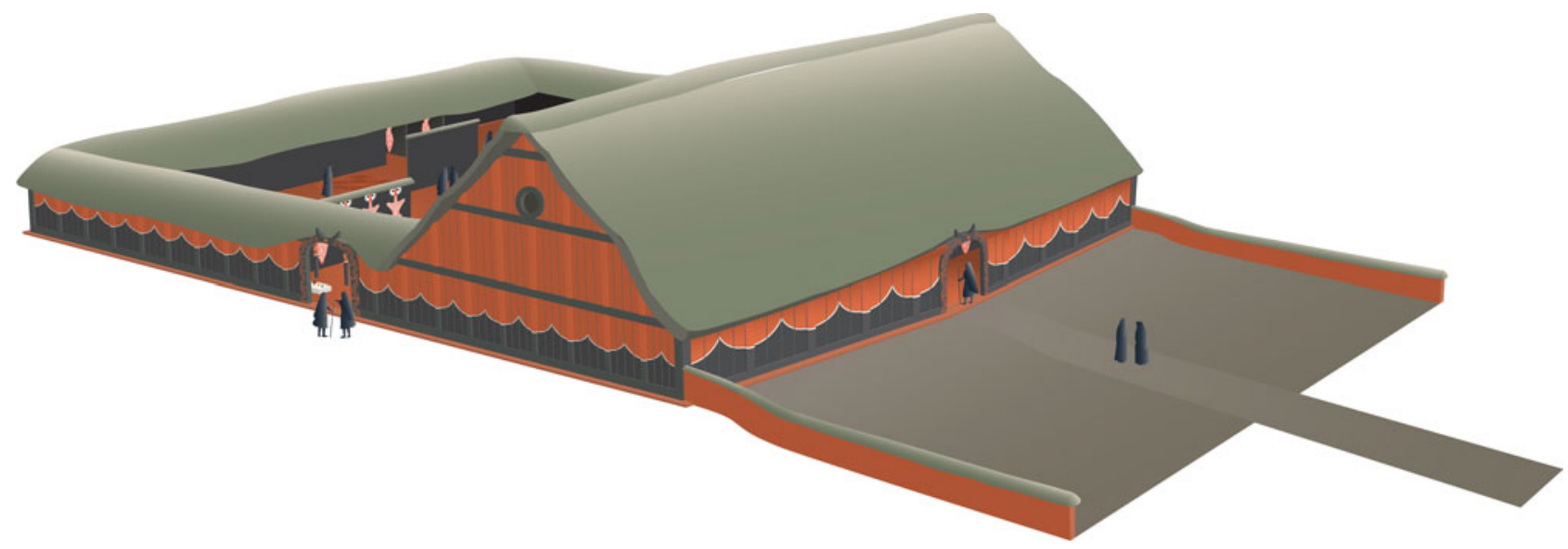

Figure 7. Reconstruction of the Nebelivka megastructure. (C. Unwin, based on data from S. Johnston.)

hint at individual production, such as the six flint projectile points all made in different ways (cf. Wiessner 1983) (Fig. 9/4-9/9), and personal identity, such as the two figurines with realistic portrait heads (Fig. 8/2). But, for the most part, the producers and the people using the objects engaged with a broadly similar range of statements about how an object should be in relation to the Trypillia Big Otherthereby forming a stable, 'Trypillia' material world (cf. Wengrow 2001). The clear preference for graded
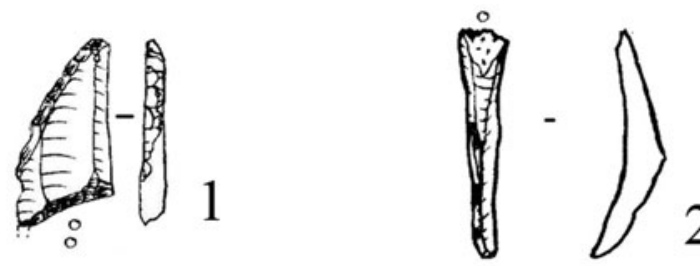

2
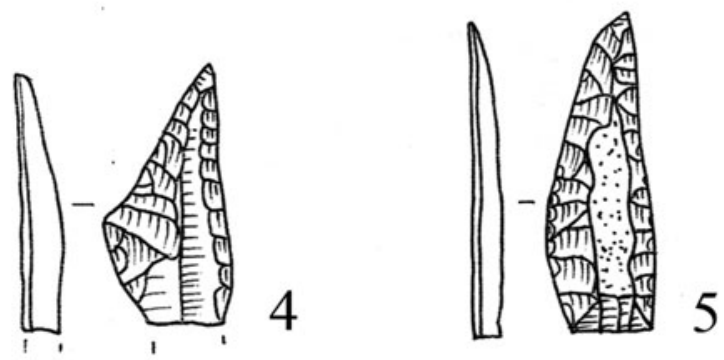

4
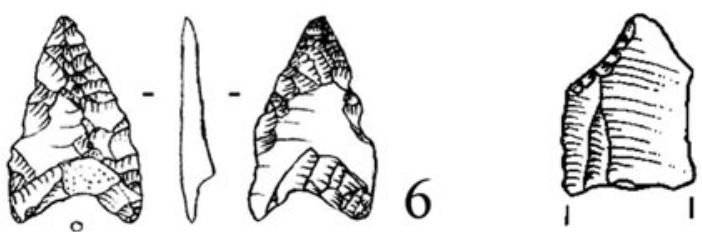

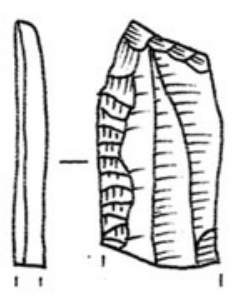

3

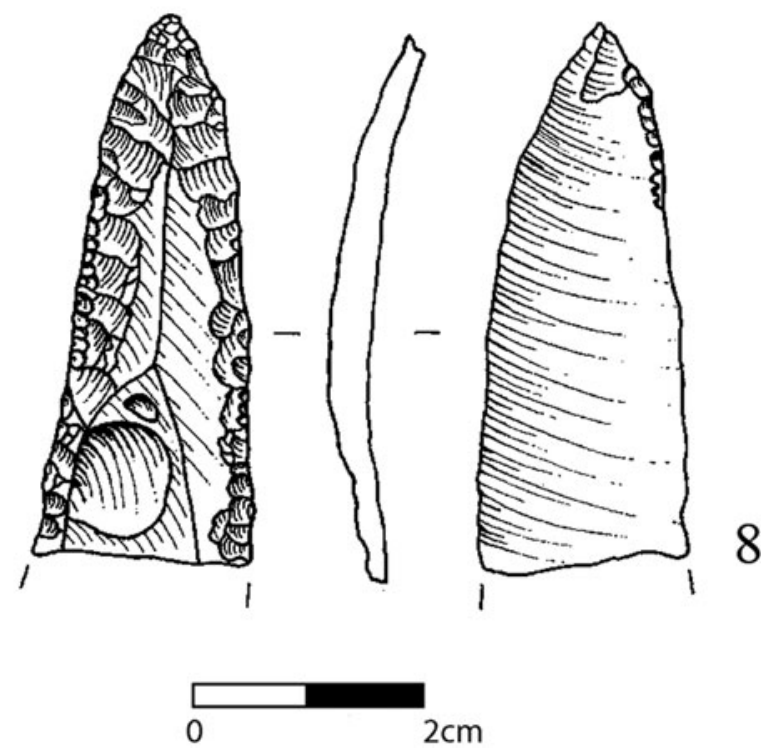

Figure 8. Megasite lithics: (1) flint rhomboid point; (2) flint lunate; (3-8) projectile points. 

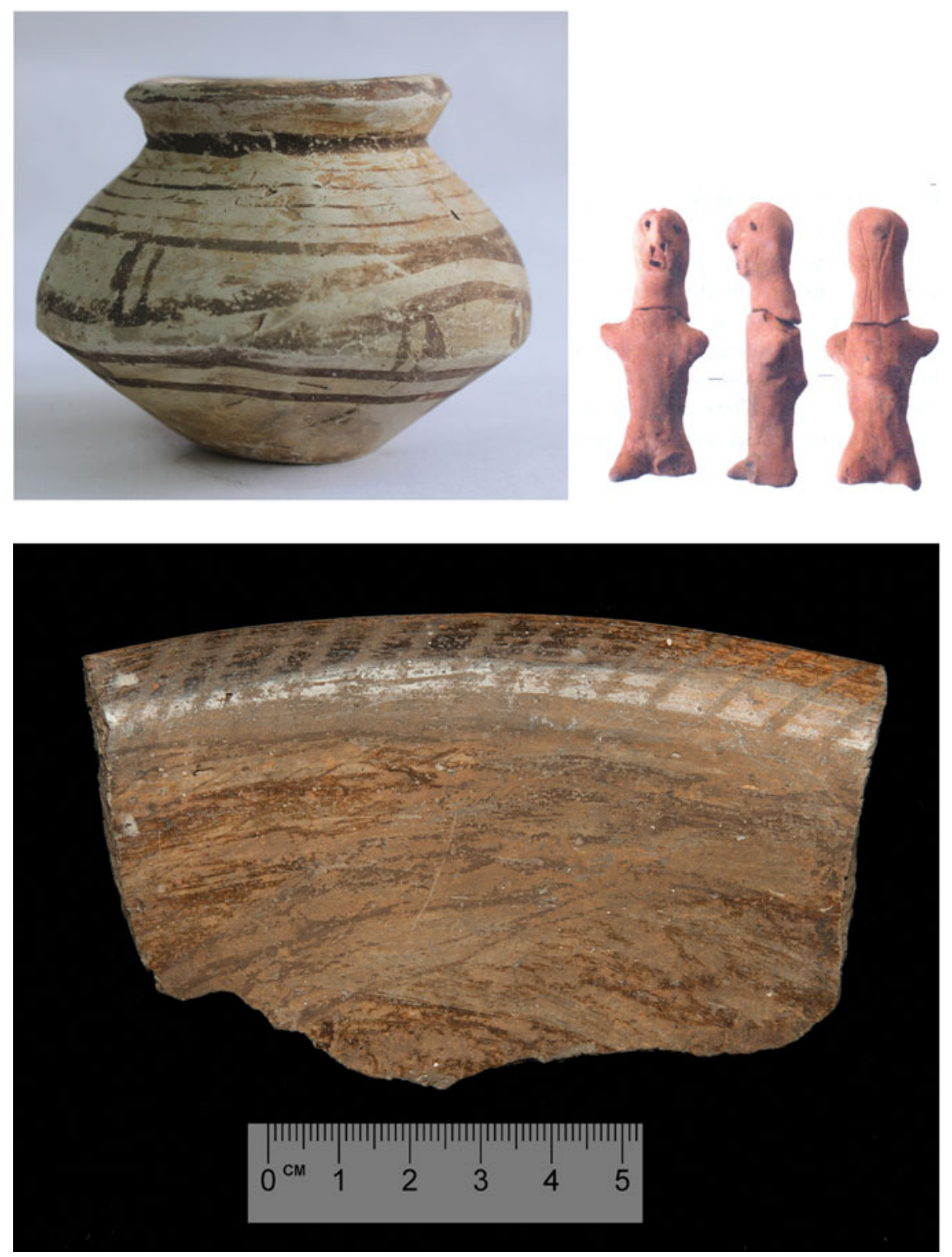

Figure 9. Megasite finds: (1) graphite-painted miniature vessel; (2) realistic fired clay figurine 'portrait' head; (3) dish with internally thickened rim with graphite decoration.

differences rather than presence/absence variation in pottery deposition indicates that a relational strategy of identity-construction was preferred, with the slow build-up of the remains of depositional events creating and maintaining the identities that related persons to all of their nested social contexts.

\section{Nebelivka foodways and landscape}

The megasite faunal sample showed the typical Middle Trypillia dominance of 90 per cent domesticates, with preferences for beef in some houses and a balanced mix of beef and mutton/lamb in other contexts (Gaydarska 2019b, section 5.3). The deposition of large quantities of animal bone in some pits suggested the prevalence of feasting in combination with artifact deposition. Despite the extensive use of flotation, the recovery rate of cereal grains and chaff was very low (six cereal grains in four excavation seasons!), with plant impressions on daub showing the common use of emmer and einkorn wheat, barley and pulses, as well as a neglect of the higher-yielding bread wheats and hexaploid barleys (Gaydarska 2019b, section 5.4). The combination of the absence of manuring scatters in the field-walking programme of the $5 \mathrm{~km}$ hinterland of the megasite (Supplementary Materials online, Fig. SM6) and the emphasis on hulled cereals 


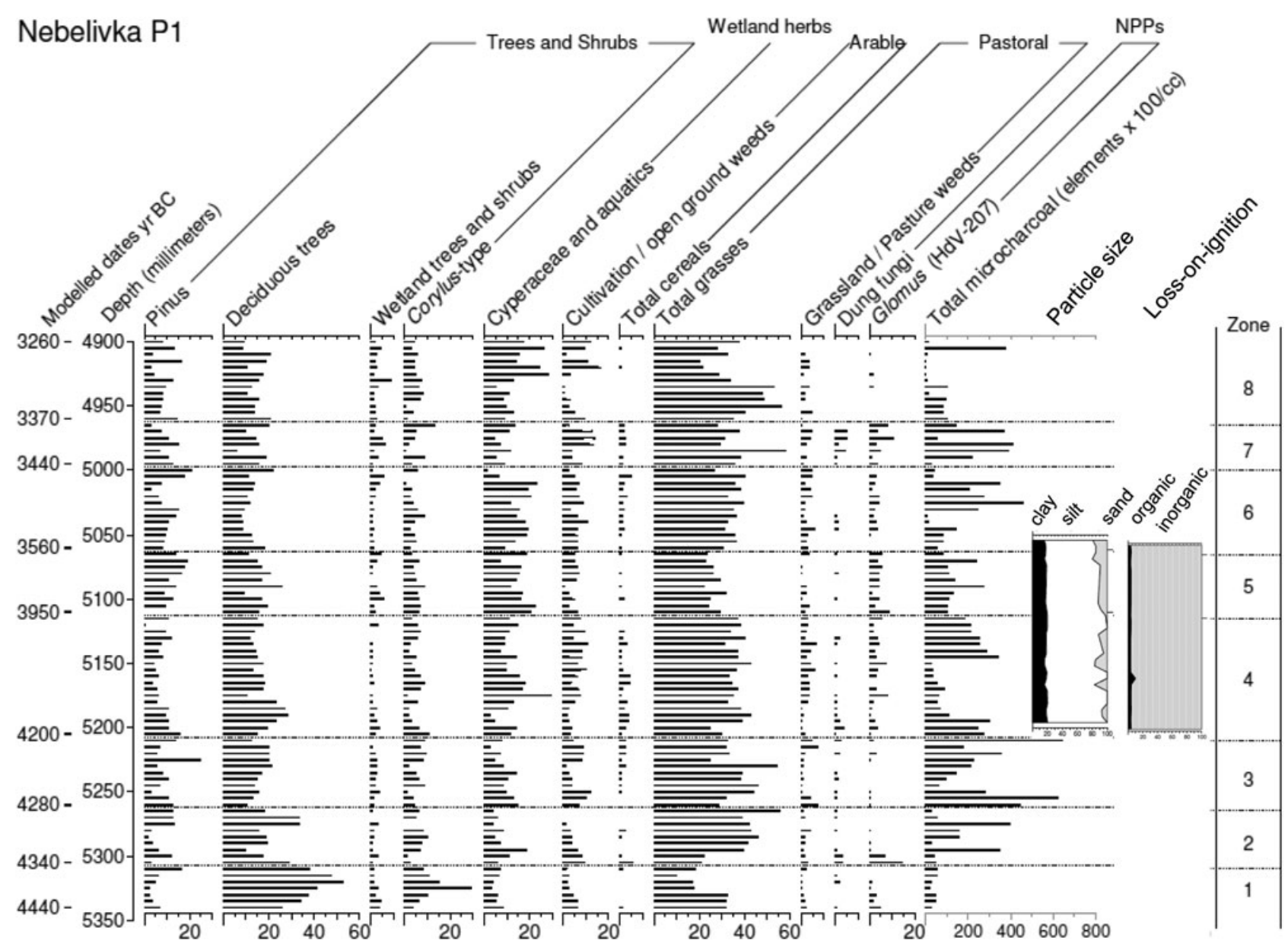

Figure 10. The Nebelivka $1 B$ core master diagram. (J. Innes.)

from the botanical data suggests a relatively inefficient, traditional 'Neolithic' form of agriculture not at all consistent with mega-populations, with no sign of arable intensification on the chernozem soils. The intriguing paucity of coeval small sites within a $15 \mathrm{~km}$ radius (Nebbia 2017) showed that the hinterland of Trypillia megasites contrasted strongly with that of early Near Eastern cities such as Uruk, with its dense network of supporting settlements (Adams 1965).

A $6 \mathrm{~m}$ sediment core from a valley $250 \mathrm{~m}$ from the edge of the megasite has provided a dated sequence of local vegetation and megasite human impacts (Albert et al. 2019) (Fig. 10). An unexpected finding was the traces of cereal pollen and a charcoal peak indicating intensive landscape burning, which both pre-dated the megasite occupation. But the greatest surprise in the Nebelivka 1B proxy records was the modest human impact on the landscape of a megasite for which others had estimated a population of 6420-8560 people (Ohlrau et al. 2016, table 5).
None of the five proxy records-deforestation, cereal pollen, micro-charcoal counts, soil erosion and water quality-showed more impact during the megasite occupation than before or after it (Fig. 10).

There is, thus, a paradox at the heart of the Trypillia megasites. On the one hand, the megasites constituted the largest settlements in fourthmillennium BC Europe, with site sizes up to 320 ha and estimated numbers of houses of almost 3000 on one site (Majdanetske: Rassmann et al. 2016). Their size, distinctive concentric settlement planning and signs of social complexity have reinforced the notion of massive, permanent, long-term dwelling. On the other hand, there is little evidence for the material or social differentiation one might have expected from such remarkable settlements. The houses fell within a narrow size range (Supplementary Materials 5, online) and there is a remarkable paucity of prestige goods, especially copper metallurgy, Spondylus ornaments and finely polished stonework. While specialists such as Diachenko (2012; cf. 
Diachenko \& Menotti 2012) have used gravity models to identify size-based settlement hierarchies, Nebbia's (2017) spatial analyses challenge this finding. Moreover, there is no evidence for a strong human impact on the local forest-steppe environment which would have followed from such postulated intensive dwelling. In short, there is a mismatch between the interpretation of a massive, permanent, long-term urban settlement and the settlement, environmental and material cultural evidence for a very different form of dwelling - smaller, less permanent and perhaps seasonal. The lack of a fine-grained internal chronology prevented the creation of a nuanced sequence of megasite development, instead prompting us to develop three alternative models for a smaller-scale form of megasite.

\section{Alternative models for Nebelivka}

The models were tested against, and met, four basic criteria: the total number of houses; the number of burnt houses; the low level of human impact as shown in the Nebelivka 1B core; and the number of coeval houses modelled by Millard (see Supplementary Materials 7, online). Two of the models are based upon the seasonal pattering of social life (cf. Wengrow \& Graeber 2015), while the third relies on smaller-scale permanent settlement. Each model presents a variant on the Nebelivka site biography, which began with a well-established settlement network in the Southern Bug catchment, some of whose site clusters included megasites of up to 150 ha (for origins, see Chapman et al. 2019), and a local settlement near the Nebelivka promontory, as attested in the Nebelivka 1B pollen core (Albert et al. 2019).

\section{The Distributed Governance Model}

The Distributed Governance Model (Gaydarska 2019b, section 6.1) (Fig. 11) envisages Nebelivka as a smaller but still permanent settlement with up to 400 contemporary houses, organized through a regional alliance of 10 descent groups which emerged from the existing settlement network. Multiple small settlements dispersed within a 100 $\mathrm{km}$ catchment area were affiliated to one of the 10 extended social groups. Each descent group drew on its wider network to complement megasite subsistence with food, salt, timber and other resources for one year before passing on the leadership role to another group. The responsibility of the smooth, heterarchical running of the megasite came with the power to take daily decisions on behalf of the people living in the settlement, but also their friends and relatives in the wider landscape. The descent groups

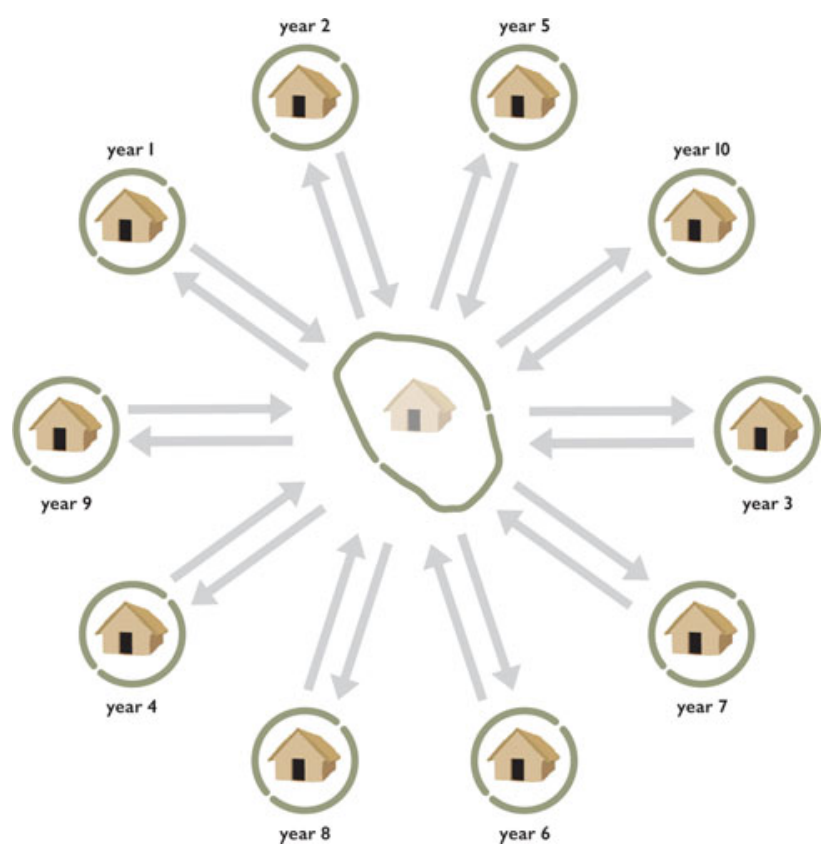

Figure 11. The Distributed Governance model. (C. Unwin.)

built a single house circuit over the first five years, with expansion into a second circuit and the inner radial streets over the following decades. Seven to ten houses were build and burnt every year, keeping the number of contemporary houses around 400, while still accounting for the low environmental impact and the final footprint of 1445 houses. Decision-making at Nebelivka was taken through a council consisting of descent group representatives, with the leading descent group in any year organizing major festivals, such as the annual 'Change of Descent Group' ceremony and minor periodic ceremonies. But political power was distributed, with each descent group in control for one year in ten. The reason behind the emergence of this settlement form is the formalization of the experience gained during previous seasonal episodes of aggregation. The benefits of the increased potential for interaction, trade, and later specialized production inspired the initial experiment of a larger permanent co-habitation of heterogeneous groups. Once the sustainability of such a settlement was established via an off-site supply network, the vitality of this form of aggregation is witnessed by $600-800$ years of continuity. The greatest strength of this model is that it fits well with the traditional view of permanent long-term occupation, but with greatly reduced population estimates. This model also best conforms to the construction of the solid timber-framed houses typical of all megasites. 

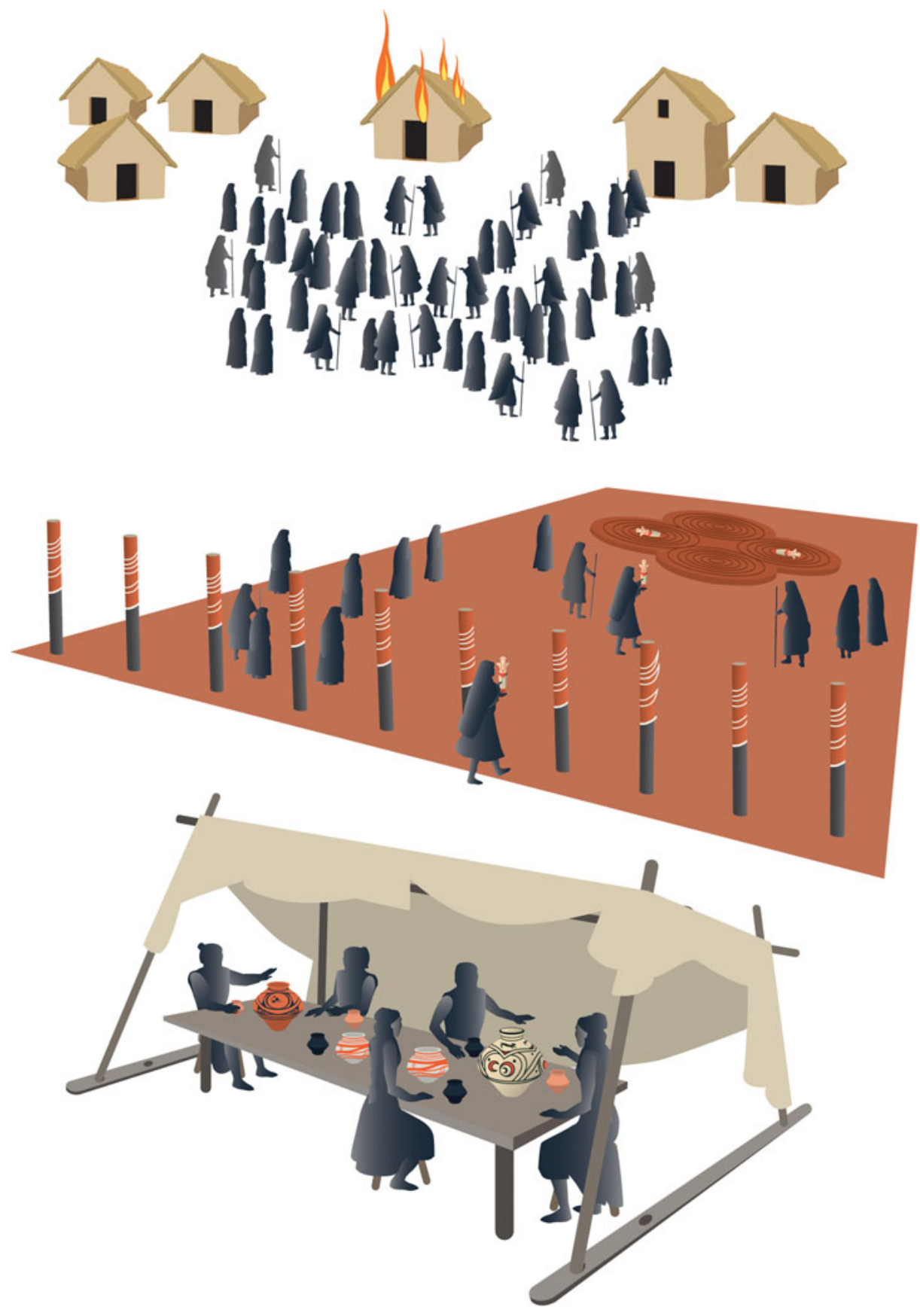

Figure 12. The Assembly model. (C. Unwin.)

The Assembly Model

The Assembly Model (Nebbia et al. 2018) (Fig. 12) interprets Nebelivka as a regional centre for largescale assembly over one month per annum, with a small group of 'Guardians' living year-round as an agro-pastoral community and maintaining the centre outside assembly times. In comparison with the Pilgrimage Model's emphasis on religious practices and a much longer visiting season (see below), the
Assembly Model exploited the shorter period for more concentrated interactions which brought a wide variety of benefits to participants, principally the opportunity to meet a far wider group of visitors than was ever possible elsewhere. The Assembly place developed out of the central settlements in previous (Phase BI) local settlement clusters. The site would have developed through the formation of Quarters, with five founded in each of the first and 
second generations and four more in the third generation-a slow development of the overall plan that was perhaps a weakness in this model. These Quarters had the dual purpose of materializing the local identities of the home communities through bottom-up planning, while at the same time providing an overall framework for the creation of a 'central' or 'Nebelivka' identity. These two identities were in tension throughout the use of the assembly site, with the Nebelivka identity supported by house-building and -burning activities, pit- and ditch-digging and communal feasting. But the 'Nebelivka' identity was dominant only at the time of the assembly, sustaining the seasonal re-structuring of society to form a regional political unit to create and run the assembly. The creation of a major assembly as the key event in the annual regional calendar would have been a big attraction to people over a wide area.

\section{The Pilgrimage Model}

The Pilgrimage Model (Chapman \& Gaydarska, in press) (Fig. 13) is an extended version of the Assembly Model, but with a much longer, eightmonth season and a more focused motivation based upon the Trypillia Big Other. This model is based upon extensive pre-existing social networks linking sites across regions, supported by the ubiquitous shared symbolic order of the Big Other. Following on from the assemblies of the earliest megasites in Phase BI, pilgrimage centres were selected for a range of different reasons by ritual leaders who became 'site guardians'. It was these guardians who prepared the ground, organized the large-scale woodland management necessary for initial house-building and negotiated with other settlements for major contributions to the construction of the site.

The key feature of the model is the massive labour input required of 'Pilgrim-Builders' to construct an entire house circuit and dig the entire perimeter ditch in the first two seasons. The advantage for this effort was the creation of a spectacularly large pilgrimage centre which would have become famous across the whole Trypillia world. Thereafter, building rates became more tightly controlled, with home communities living in the same houses for a succession of one-month visits. In addition to the religious experience, healing, exchange and meeting with a diversity of people were all important parts of pilgrimage (McCorriston 2011). This model provides the most cogent explanations for many of the planning elements of the megasitenot only the location and multiplicity of Assembly

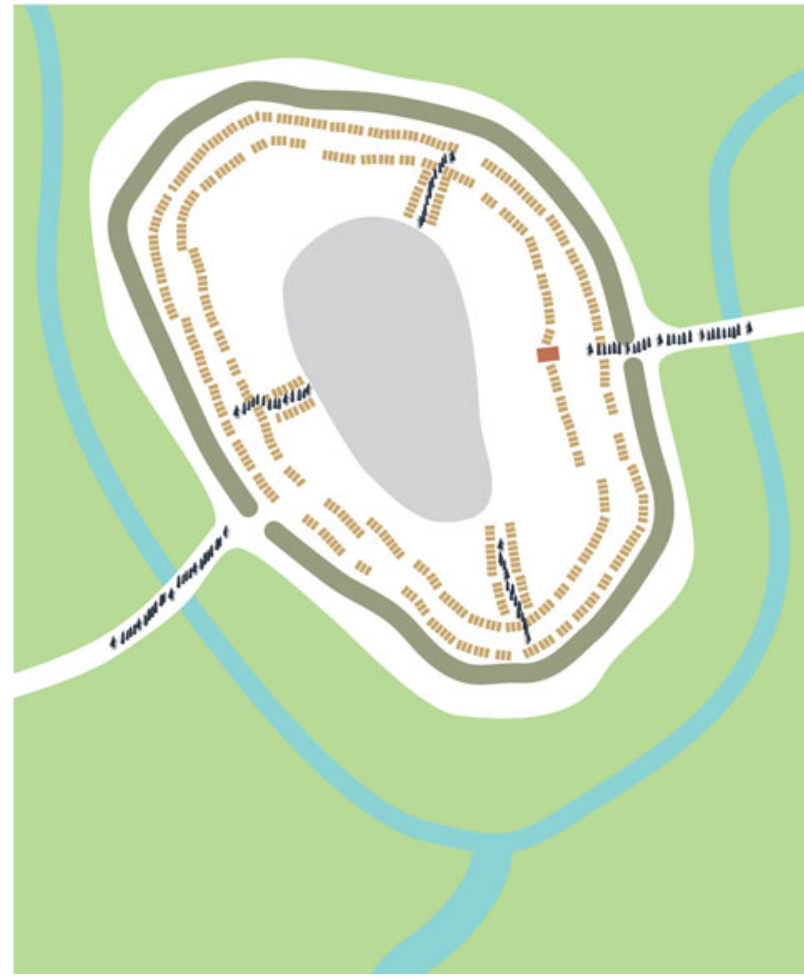

Figure 13. The Pilgrimage model. (C. Unwin.)

Houses, but also the concentric ditch and house circles and the radial streets, which are all interpreted as framing devices for processions from the outside of the site into the sacred open inner area.

Given that each model has its advantages and disadvantages, we have so far found it impossible to decide on any single model, leaving an element of ambiguity to the future interpretation of the Nebelivka megasite. Each model can best explain a key feature of the megasite plan-the Distributed Governance Model relates well to the multiplicity of timber-framed houses, the Assembly Model requires an inner open area for its principal meeting space, while the form of the concentric house circuits and inner radial streets would have created ideal processional spaces for the Pilgrimage Model. The Distributed Governance Model was inspired by K. Hirth's (2008) views on the modus operandi of the Mesoamerican altepetl and Hahn's (2012) work on segmentary societies in Africa, while pilgrimages have recently been discussed in comparable terms in British prehistory (Loveday 2015) and the Near East (McCorriston 2011). Equally, the importance of assembly sites has been widely discussed for Stonehenge (Parker Pearson 2015), Angkor Wat 
Bisserka Gaydarska, Marco Nebbia and John Chapman

(Lucero et al. 2015), Cahokia (Pauketat \& Emerson 2000) and in a special issue of World Archaeology (Semple 2018).

The failure of any model to explain all of the megasite planning elements is an indicator that we cannot yet reject any model for the growth of the Nebelivka megasite. This conclusion inevitably complicates the debate over the urban status of megasites, to which we now turn.

\section{Independent European urbanism}

The initial impetus for pursuing an urban agenda in the interpretation of Nebelivka, and the megasites more generally, was the large settlement size. Very soon, however, it became obvious that such a path of box-ticking (e.g. large size being one of the few traits most urban commentators agree on) will relegate these sites to what they were before the Project-an exception that proves the rule (Liverani 2013). Since the accumulation of many strands of evidence proved the exceptional nature of Nebelivka, it was imperative that the exceptions now formed an alternative rule.

Building on Cowgill's (2004) insights, a proposition for measurement of 'urban-ness' was put forward that followed Cartwright and Runhardt's (2014) approach to measurement in the social sciences (Gaydarska 2016). Such an approach has been called 'relational', as its core premise is that various categories of sites, including urban, emerge in relation to each other rather than absolutely. Thus, for example what constitutes a city (or a town) in second-millennium $\mathrm{BC}$ China could not and should not be a mould applied to AD eleventhcentury North America. Such a mould usually comes in either one of three definitions-Childe's (1950) check-list, Wirth's (1938) sociological definition and Michael Smith's (2007) functional definition - or a variant on one of these three definitions or a combination of two or three of the definitions. For all the advantages such definitions have, they 'flatten' emerging phenomena, developed cities and sites with a long urban legacy into one single 'idealized' view of what should be considered as urban. The relational approach avoids such an amalgamation of individual and collective agencies, historical and landscape contexts and rapidly or slowly changing local circumstances by looking for emerging and recurring categories of sites in relation to preceding and contemporary settlement patterns. The difference, then, is not measured by presence/absence, absolute numbers or on a gradient scale, as suggested by Michael Smith (2016), but by identifying meaningful local markers in what Cartwright and Runhardt (2014) call the characterization of those social phenomena to be measured. Any characterization should meet the following conditions: it should be useful for its purpose, it is socially constructed, it should be not too general but it should also not create boundaries. The characterization of the category 'urban' in the Trypillian context in general, and Nebelivka in particular, has nine constituents-the territory to which a site is central, site size, population numbers, population heterogeneity, the concentration of skilled labour and management, the built environment and formalized spaces with special functions, the scale of subsistence, the potential to be a node and re-distribution centre in a widereaching exchange network and the overall social structure. The small (4.5 ha) Trypillia settlement of Grebeni (Kolesnikov 1993) (Supplementary Materials 8, online) was then selected as a welldocumented comparandum for the 238 ha Nebelivka along these nine lines, not just to point out obvious contrasts in scale, but to demonstrate the profound difference in lived experience and a wide range of social and technological potential (see Gaydarska 2019b, section 6.3).

As an example, we select only two-probably the most contentious - of the nine elements-the size of the sites and their population. The density of building on the smaller settlement was nine houses per hectare, providing enough space for small gardens and/or pens in the vicinity of each house. With a maximum population of $c .300$ people (38 dwellings $\times 8$ inhabitants), additional agricultural plots were needed to complement the plant-based component of their diet. Even the more distant of these fields would not have been more than half-an-hour's walk from the settlement. With just 38 houses, members from each neighbourhood would have seen each other daily, while interneighbourhood encounters were, if not a daily, then a weekly event. The residential density at Nebelivka was broadly similar or even lower (6 houses/ha) and although allotments and pens may have been nearby, the complementary arable plots and pastures to sustain a population in its thousands would have been located at a serious distance from the megasite-probably hours away. More people meant not only more food, water and waste, but also a more complex use of space not just for habitation, subsistence and rituals but requiring planning, logistics and management. And since the regular scale of face-to-face contacts on settlements rarely exceeded 450-500 people (Dunbar et al. 2010; Forge 1972), the daily and weekly habitus of any occupant 
of Nebelivka may at first sight be like that in any small site; however, this number is $1 / 8$ to $1 / 10$ of the population of Nebelivka. While everyone could potentially have seen or met everyone else, people's interactions were probably channelled so that there were some more regular and other less regular meetings, introducing heterogeneity into social interactions and a diversity of household locations with differing degrees of connectivity.

The social, economic and personal implications of living on a small 4.5 ha and the rare $>150$ ha sites are so different that we argue that there was no possibility that the Nebelivka megasite was simply a very large example of a typical small rural settlement. Such an equation would be a categorical mistake, of the kind which suggests that aircraft carriers are simply very large examples of yachts. We argue that megasites were perceived, experienced and functioned in a very different way from any smaller previous and contemporary site. We do not know the emic name for megasites, but we call them 'urban' since Trypillia megasites exhibited the same order of qualitative and quantitative differences from the typical small Trypillia settlement as the city of Uruk did from small tells in the Fertile Crescent, or Roman London from the villas of southeast England. The fact that this class of megasites can be dated to the earliest part of the fourth millennium $\mathrm{BC}$ - several centuries earlier than urban Uruk-offers further ground for considering their significance in world prehistory in a new light.

It is not just Trypillia megasites that have suffered an oversight in global urban debates. It is only in the last 10 years that the significance of a certain class of sites has finally been recognized. Low-density urbanism is now an acknowledged alternative trajectory of urban development in several regions in the world, such as Southeast Asia and Central America (Lucero et al. 2015), with continuous expansion to include more anomalously large sites from across the globe (Fletcher \& Kim submitted). The Trypillia megasites share all of the principal characteristics of the low-density urban sites (Fletcher 2009), such as the short time taken from the origins of agriculture to the formation of urban communities, the transformation from higher-density to lower-density large sites, the importance of major building projects, kinshipbased, house-oriented planning practices, seasonal settlement, the relative insignificance of the mortuary domain and the rarity of an urban legacy. This means that the Trypillia megasites were not only the earliest known urban sites in the world, but also the earliest known low-density urban sites in the world. But, whatever the label we attribute to the megasites, there remains the question of the origins of such remarkable sites.

\section{The origins of Trypillia megasites}

The North Pontic forest-steppe zone constituted a mosaic of deciduous woodland of lime, elm, oak and hazel interspersed with open parkland (Kremenetski 1995; 2003) in rolling loess plateaux rarely exceeding 250 masl, where some of the most fertile soils in Europe - the chernozems-had developed from the Mid-Holocene onwards (Shumilovskikh et al. 2017). The Trypillia group were pioneering agropastoral communities which introduced domesticated crops and animals, large timber-framed houses and a wide range of novel material culture to the foreststeppe zone. A key area for a concentration of megasites, including the earliest examples, was the south Bug-Dnieper interfluve (Fig. 14). The absence of significant environmental differences between this zone and other forest-steppe areas with few or no megasites suggests that social rather than environmental factors were responsible for this concentration of megasites (Nebbia 2017). So what was the cultural background from which they emerged? What were the changes in the Trypillia world to which megasites were a possible response? And what (dis)advantages did Trypillia megasites bring to their world?

We can summarize the picture of Trypillia settlement at Phase BI/II (c. 4200-4000 BC), before the emergence of the first planned megasites, in the following way. The three key material traits of the Big Other-the house, the pottery and the figurines (Fig. 3) - were all demonstrably part of the initial agro-pastoral expansion east of the Dniester valley, proving to be the most attractive elements of Trypillia communities to the Forest Neolithic groups, who produced a limited range of fine wares but lacked figurines and rectangular houses. The BI/II network brought modest amounts of copper and Volhynian flint from the Western CT area. While some elements of what would become central elements of Phase BII megasite planning had already developed by Phase BI/II, they were not apparent on the largest sites and no Phase BI/II site showed more than a single 'advanced' planning element.

The emergence of large CT settlements by 4000 BC is part of two long-term settlement trends-landscape infilling northwards from the southern Bug valley and increased site clustering into small groups of sites, occasionally with more than one large site in the cluster (Supplementary Materials Figure SM9, online). As the first farmers in the North Pontic steppe, the CT network came into regular contact 


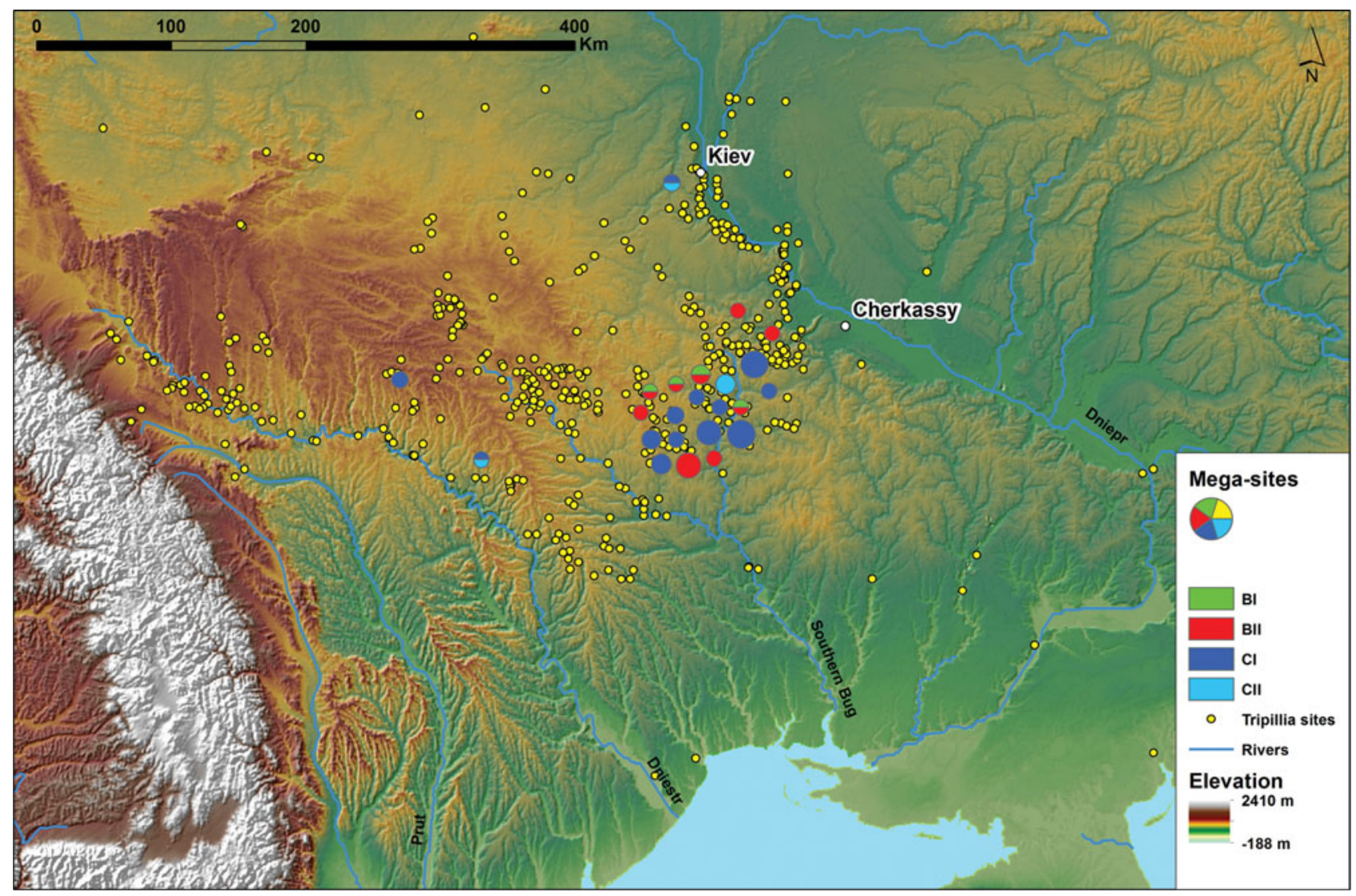

Figure 14. Distribution of Trypillia megasites (large circles) by Phase and smaller settlements. (M. Nebbia.)

with local foragers (the so-called 'Forest Neolithic'), who lived in small, possibly seasonal settlements (Kotova 2003). While the details of interactions between local foragers and incoming farmers remain unclear, the varied mix of site types and lifeways would have broadened the CT awareness of temporalities different from their own. The dramatic 15-fold increase in site sizes in a period of a few centuries depended on support from other, smaller settlements in a local buffering network (Halstead 1982) and further exposed the CT network to the reality of inter-settlement differences. In these ways, it became possible to imagine massive sites with a temporality which differed from that of the usual settlement.

Three key innovations affecting the growth of CT settlements concerned the creation of coherent settlement plans, the introduction of painted pottery and changes in the importance of animal husbandry (Chapman et al. 2019). Changes in settlement planning led to the novel combination of planning elements such as concentric house circles, inner radial streets and an inner open area into a single coherent megasite plan. The creation of two new types of large vessel widened the scope of household grain storage (Ellis
1984) and communal consumption and feasting. Decoration of fine wares in black paint required an expansion of exchange networks to obtain exotic manganese pigments. The combination of these changes led to a new class of fine painted wares more common than the rare prestige goods, leading in turn to new opportunities for domestic and public deposition. The preference for more domestic animals (over 90 per cent at Nebelivka: Gaydarska 2019b, section 5.3) gave households a greater control over animal keeping and opportunities for feasting. It was the integration of all three sets of practices at megasites that enabled scalar transformations in the quantity of people involved, the quantity of material involved and the quantity of house-building and -burning involved.

There is still a residual concern that these structural changes were necessary but insufficient factors in the emergence of these extraordinary sites. It is hard to envisage the scale of social interaction at an early megasite, with visitors meeting people from 30-50 home communities in contrast to the previous limited face-to-face engagements. In return for commitment to corporate projects (ditch- and pit-digging, the gathering of materials and house-building), early 
residents participated in an unprecedented range of special events, from 'local' Neighbourhood pit deposition and feasting to annual 'global' celebrations of the megasite itself. There was an element of success feeding success, with tales of the events, their scale and magnificence, spreading through the Trypillia network and attracting more and more visitors to the megasite. The stimulus of the megasite community for the creation of alliances made Nebelivka and other early megasites particularly special centres. It was this upward trend in alliance-formation and the richness of interactions that were the sparks leading to the emergence of megasites.

Given these important developments at early megasites, can we identify the key advantages to participating in megasite practices? The decision to develop a megasite into a more permanent arrangement was an agreement made by the whole network, as mediated by representatives of the many home communities whose members would settle at the megasite. This decision had several implications. The first was to consolidate alliances between those clans participating in the megasite dwelling, bringing those groups closer to each other than to other neighbouring clans. Secondly, the permanent arrangement led to a more formalized site plan which, in turn, supported the idea of a community identity. Thirdly, the increased place-value accruing to a megasite led to the general growth in importance of places where large gatherings were held. And, fourthly, the unprecedented scale of exchange occurring on such early megasites led to cumulative social advantages for those dwelling on such sites. The sum total of these advantages led to the attraction of megasite lifeways to a wider pool of people living in the extended Nebelivka network of $100 \mathrm{~km}$ radius. Problems of scalar stress would undoubtedly have caused more disputes than on a typical small Trypillia settlement. In the case of the two seasonally based models, the options of leaving early or simply moving to another part of a huge site were always open; disputes may well have been harder to manage or resolve in the third, permanent settlement model (see above).

In summary, the diversity of pre-megasite settlement experience in the southern Bug-Dnieper interfluve provided settlers with the possibility of imagining different kinds of site-small settlements and large, seasonal or permanent centres of assembly-which enabled the emergence of the megasites. Major changes in settlement planning and painted pottery production, as well as changes in animal keeping, can be closely related to the origins of megasites. But the key innovation which co-emerged with megasites was the potential for an unprecedented scale of interaction-whether personal (exchange, feasting) or institutional (alliance formation).

\section{Conclusions}

Our principal finding is that, in a relational sense, Trypillia megasites are currently the earliest known examples anywhere on earth of urban settlements and, indeed, low-density urban settlements. While there were many small Trypillia sites which accorded well with Gabriel Cooney \& Eoin Grogan's $(1999,232)$ characterization of the Neolithic as 'local worlds linked by exotic elements', this description does not fit the Trypillia megasites. What is perhaps surprising for most archaeologists is that there were at least two routes to urbanism before the state in the fourth millennium BC (Wengrow 2015) - the Mesopotamian route, with centralized management, a massive exchange network (the Uruk Expansion) and a highly visible urban legacy, and the Trypillia megasites lowdensity route with more limited exchange networks and far less materialization of social difference. Whichever of the three alternative models for Nebelivka is accepted (Figs. 12-14), each model shares the same characteristics of a much smaller population estimate than had previously been accepted, a social model which is heterarchical and with no obvious signs of centralized management, a constant but lowintensity reliance of exotic materials in a wide-ranging exchange network and the total absence of any urban legacy for three millennia. While one model favours smaller-scale permanent settlement, the other two models rely on a seasonal mode of settlement, in which the great mass of Nebelivkans were present for only one month per year-whether a month in an eight-month pilgrimage season or a one-month period of Assembly. Each model acknowledges the key roles of bottom-up settlement planning, local depositional practices, house-burning and the creation of memory mounds. Our thinking about complex societies will henceforth need to include both of these fourthmillennium BC pathways to urbanism into account. It is important to underline that neither route involved a high degree of political or economic centralization.

At the end of this article, we return to the origins of the megasites. At c. $4500 \mathrm{BC}$, a settlement covering 150 ha had never been experienced anywhere in the world. However much we improve the quality of our data for the mid fifth millennium $\mathrm{BC}$, what we still need to do is to understand how Trypillia people could imagine the possibility of these early megasites, in the same way as Benedict Anderson (1991) discusses imagined political communities in the Early 
Modern period or Maurice Bloch (2008) discusses the centrality of human imagination to the development of transcendent religious groups. For to experience an utterly unprecedented settlement form is to make a giant leap into the dark-to risk, to improvise and to generate novel social forms. In many ways, the challenge to imagine unprecedented settlement forms was greater than the challenges of megasite sustainability. For during a period of 800 years, megasites continued to be the key aggregation sites in the Ukrainian foreststeppe. This major cultural achievement has only recently been recognized and merits wider exposure.

\section{Notes}

1. This Project - "Early urbanism in prehistoric Europe?: the case of the Tripillye mega-sites" - was funded by a grant from the Arts and Humanities Research Council (Grant No. AH/I025867). The bulk of the Project data is available on the ADS platform <https://doi.org/ 10.5284/1047599>, while the Project's interpretative monograph (Gaydarska 2019b) will be downloadable from the De Gruyter website.

2. From the perspective of research trajectories, it is interesting that the discussion of megasite origins came at the very end of the Project.

3. This remains a problem for all students of the Trypillia phenomenon. For landscapes, the intensive, systematic fieldwalking of even 50 per cent of the Nebelivka $5 \mathrm{~km}$ radius microregion of $80 \mathrm{sq}$. $\mathrm{km}$ took more than three seasons to complete (Gaydarska 2019b, chapter 3), while the Taljanki megasite team has been excavating one or two burnt houses per annum for over 35 years (Kruts 2012), with over 2000 houses to go!

4. The earliest known CT cemeteries date to the latest Trypillia CII phase (Dergachev 1978).

\section{Supplementary material}

The supplementary material for this article can be found at https://doi.org/10.1017/S0959774319000301.

\section{Acknowledgements}

We are happy to acknowledge the varied but essential contributions of many institutions and people to the success of the Project: Durham University and the Kyiv Institute of Archaeology, the contributors to the Project monograph and other participants in excavation, fieldwork and postexcavation research (for extended acknowledgements, see Supplementary Materials 10 online).

\section{Bisserka Gaydarska Independent Scholar \\ Email: b_gaydarska@yahoo.co.uk}

\section{Marco Nebbia \\ Department of Archaeology \\ University of Durham \\ South Road \\ Durham DH1 3LE \\ UK}

Email:marco.nebbia@durham.ac.uk

John Chapman

Department of Archaeology

University of Durham

South Road

Durham DH1 3LE

UK

Email: j.c.chapman@durham.ac.uk

\section{References}

Adams, R., 1965. Land Behind Baghdad: A history of settlement on the Diyala plains. Chicago (IL): University of Chicago Press.

Albert, B., J. Innes, K. Kremenetskiy, A. Millard, B. Gaydarska, M. Nebbia \& J. Chapman, 2019. What was the ecological impact of a Trypillia megasite occupation? Multi-proxy palaeo-environmental investigations at Nebelivka, Ukraine. Vegetation History and Archaeobotany. https://doi.org/10.1007/ s00334-019-00730-9

Anderson, B., 1991. Imagined Communities. Reflections on the origins and spread of nationalism (2nd edn.). London/ New York: Verso.

Bloch, M., 2008. Why religion is nothing special but is central. Philosophical Transactions of the Royal Society $B$ 363, 2055-61.

Cartwright, N. \& R. Runhardt, 2014. Measurement, in Philosophy of Social Science: A new introduction, eds N. Cartwright \& E. Montuschi. Oxford: Oxford University Press, 265-87.

Chapman, J., 2017. The standard model, the maximalists and the minimalists: new interpretations of Trypillia. Journal of World Prehistory 30(3), 221-37.

Chapman, J., in prep. Forging Identities in Balkan Prehistory: Dividuals, individuals and communities, 7000-3000 BC. Cambridge: Cambridge University Press.

Chapman, J. \& P.M. Dolukhanov, 1993. Cultural transformations and interactions in eastern Europe: theory and terminology, in Cultural Transformations and Interactions in Eastern Europe, eds. J. Chapman \& P. M. Dolukhanov. Aldershot: Avebury, 1-36.

Chapman, J. \& B. Gaydarska, 2016. Low-density urbanism: the case of the Trypillia group of Ukraine, in Eurasia at the Dawn of History. Urbanisation and social change, eds. M. Fernández-Götz \& D. Krausse. Cambridge: Cambridge University Press, 81-105.

Chapman, J. \& B. Gaydarska, 2018. The Cucuteni-Trypillia 'Big Other'-reflections on the making of millennial 
cultural traditions, in Between History and Archaeology. Papers in honour of Jacek Lech, eds D. Werra \& M. Woźny. Oxford: Archaeopress, 267-77.

Chapman, J. \& B. Gaydarska, 2019. Concepts of time and history on Chalcolithic tell settlements and Trypillia mega-site, in Time and History in Prehistory, eds. S. Souvatzi, A. Baysal \& E.L. Baysal. London: Routledge, 147-71.

Chapman, J. \& B. Gaydarska, in press. The pilgrimage model for Trypillia mega-sites: the case of Nebelivka, Ukraine, in C. Schuster Festschrift, eds. V. Stîrbu \& A. Comşa. Bucureşti.

Chapman, J., B. Gaydarska \& M. Nebbia, 2019. The origins of Trypillia mega-sites, in Frontiers in Digital Humanities special issue 'Where Do Cities Come From and Where Are They Going To? Modelling Past and Present Agglomerations to Understand Urban Ways of Life'. https://doi.org/10.3389/ fdigh.2019.00010

Chapman, J., M. Videiko, B. Gaydarska, N. Burdo \& D. Hale, 2014a. An answer to Roland Fletcher's conundrum? Preliminary report on the excavation of a Trypillia mega-structure at Nebelivka, Ukraine. Journal of Neolithic Archaeology 16, 135-57. http:// www.jungsteinsite.de/

Chapman, J., M. Videiko, B. Gaydarska, et al., 2014b. The planning of the earliest European proto-towns: a new geophysical plan of the Trypillia megasite of Nebelivka, Kirovograd Domain, Ukraine. Antiquity 88(339), online gallery: http://www.antiquity.ac. uk/projgall/chapman339/

Chapman, J., M. Videiko, D. Hale, et al., 2014c. The second phase of the Trypillia megasite methodological revolution: a new research agenda. European Journal of Archaeology 17(3), 369-406.

Childe, V.G., 1950. The urban revolution. The Town Planning Review 21(1), 3-17.

Childe, V.G., 1958. The Prehistory of European Society. London: Cassell.

Christophersen, A., 2015. Performing towns. Steps towards an understanding of medieval urban communities as social practice. Archaeological Dialogues 22(2), 109-70.

Cooney, G. \& E. Grogan, 1999. Irish Prehistory: A social perspective. Dublin: Wordwell.

Cowgill, G., 2004. Origins and development of urbanism: archaeological perspectives. Annual Review of Anthropology 33, 525-49.

Dergachev, V., 1978. Vykvhatintski mogilnik [The Vykvhatintski cemetery]. Kishinev: Tsiintsa.

Dergachev, V., 2002. Two studies in defence of the migration concept, in Ancient Interactions: East and west in Eurasia, eds K. Boyle, C. Renfrew \& M. Levine. Cambridge: McDonald Institute for Archaeological Research, 93-112.

Diachenko, A., 2012. Settlement system of West Tripolye culture in the Southern Bug and Dnieper interfluve: formation problems, in The Tripolye Culture
Giant-settlements in Ukraine: Formation, development and decline, eds. F. Menotti \& A. KorvinPiotrovskiy. Oxford: Oxbow, 116-38.

Diachenko, A. \& F. Menotti, 2012. The gravity model: monitoring the formation and development of the Tripolye Culture giant-settlements in Ukraine. Journal of Archaeological Science 39(8), 2810-17.

Dunbar, R.M., C. Gamble \& J. Gowlett, 2010. The social brain and the distributed mind, in Social Brain, Distributed Mind, eds R. Dunbar, C. Gamble \& J. Gowlett. (Proceedings of the British Academy 158.) Oxford: Oxford University Press, 3-16.

Ellis, L., 1984. The Cucuteni-Tripolye Culture. A study in technology and the origins of complex society. (BAR International series S217.) Oxford: British Archaeological Reports.

Flannery, K.V. \& J. Marcus, 2012. The Creation of Inequality: How our prehistoric ancestors set the stage for monarchy, slavery, and empire. Cambridge (MA): Harvard University Press.

Fletcher, R., 1995. The Limits to Settlement Growth. Cambridge: Cambridge University Press.

Fletcher, R., 2009. Low-density, agrarian-based urbanism: a comparative view. Insights (Durham University, Institute of Advanced Study) 2(4), 2-19.

Fletcher, R. \& N. Kim (eds), submitted. Anomalous Giant Settlements. Tucson (AZ): University of Arizona Press.

Forge, A., 1972. Normative factors in the settlement size of Neolithic cultivators (New Guinea), in Man, Settlement and Urbanism, eds P.J. Ucko, G. W. Dimbleby \& R. Tringham. London: Duckworth, 363-76.

Gaydarska, B., 2016. The city is dead-long live the city! Norwegian Archaeological Review 49, 40-57.

Gaydarska, B., 2017. Introduction: European prehistory and urban studies. (Special Issue on Urbanism.) Journal of World Prehistory 30(3), 177-88.

Gaydarska, B., 2019a. Trypillia megasites-the first cities in Europe?, in Coming Together: Comparative approaches to population aggregation and early urbanization, ed. A. Gyucha. Buffalo (NY): SUNY Press, 165-87.

Gaydarska, B., 2019b. Early Urbanism in Europe: The Trypillia mega-sites of the Ukrainian forest-steppe. Berlin: De Gruyter.

Gaydarska, B, 2019c. 'If we want things to stay as they are, things will have to change': the case of Trypillia, in Habitus? The social dimension of technology and transformation, eds S. Kadrow \& J. Müller. Leiden: Sidestone, 47-69.

Hahn, H.-P., 2012. Segmentary societies as alternatives to hierarchical order: sustainable social structures or organization of predatory violence?, in Beyond Elites. Alternatives to hierarchical systems in modelling social formations, eds. T.L. Kienlin \& A. Zimmermann. Bonn: Habelt, 33-40.

Halstead, P., 1982. The economy has a normal surplus: economic stability and social change among early 
farming communities of Thessaly, Greece, in Bad Year Economics: Cultural responses to risk and uncertainty, eds P. Halstead \& J. O'Shea. Cambridge: Cambridge University Press, 68-80.

Hirth, K., 2008. Incidental urbanism: the structure of the Prehispanic city in central Mexico, in The Ancient City: New perspectives on ancient urbanism, eds. J. Marcus \& J. Sabloff. Santa Fe (NM): School for Advanced Research Press, 273-98.

Johnson, G., 1982. Organizational structure and scalar stress, in Theory and Explanation in Archaeology, eds. C. Renfrew, M. Rowlands \&. B. Segraves. New York (NY): Academic Press, 389-421.

Kolesnikov, A.G., 1993. Tripolskoe obshtestvo sredengo Podneprovya. Opit socialnih rekonstruktsiya $v$ arheologii [Trypillia society along the Middle Dniepr. An attempt at social reconstruction in archaeology]. Kiev: Naukova Dumka.

Korvin-Piotrovskiy, A., 2003. Teoreticheskie problemy issledovanij poselinij-gigantov [Theoretical problems of the investigations of settlement-giants], in Tripolian Settlement-Giants: The international symposium materials, eds. A. Korvin-Piotrovskiy, V. Kruts \& S. Ryzhov. Kiev: Korvin-press, 5-7.

Kotova, N.S., 2003. Neolithization in Ukraine. (BAR International series S1109.) Oxford: BAR Publishing.

Kremenetski, C., 1995. Holocene vegetation and climate history of southwestern Ukraine. Review of Palaeobotany and Palynology 85(3-4), 289-301.

Kremenetski, C., 2003. Steppe and forest-steppe belt of Eurasia: Holocene environmental history, in Prehistoric Steppe Adaptation and the Horse, eds C. Renfrew \& M. Levine. Cambridge: McDonald Institute for Archaeology, 11-27.

Kruts, V., 1989. K istorii naseleniya tripolskoj kultury v mezhdurechye Yuzhnogo Buga i Dnepra [Contribution to the history of the Trypillia culture in the Southern Bug-Dnieper interfluve], in Pervobytnaya Archeologiya: Materialy $i$ Issledovaniya [Primeval archaeology: materials and investigations], ed. S. Berezanskaya. Kiev: Naukova Dumka, 117-32.

Kruts, V., 2012. Giant-settlements of Trypolye Culture, in The Tripolye Culture Giant-Settlements in Ukraine: Formation, development and decline, eds F. Menotti \& A. Korvin-Piotrovskiy. Oxford: Oxbow, 70-78.

Lacan, J., 1988. Book II. The Ego in Freud's Theory and in the Technique of Psychoanalysis, 1954-1955, ed. J.-A. Miller. New York (NY): W.W. Norton.

Liverani, M., 2013. Power and citizenship, in The Oxford Handbook of Cities in World History, ed. P. Clark. Oxford: Oxford University Press, 164-80.

Loveday, R., 2015. Religious routine and pilgrimage in the British Isles, in The Oxford Handbook of Neolithic Europe, eds. C. Fowler, J. Harding \& D. Hofmann. Oxford: Oxford University Press, 463-79.

Lucero, L., R. Fletcher \& R. Coningham, 2015. From 'collapse' to urban diaspora: the transformation of low-density, dispersed agrarian urbanism. Antiquity $89,1139-54$.

Manzura, I., 2005. Steps to the steppe: or, how the north Pontic region was colonised. Oxford Journal of Archaeology 24(4), 313-38.

Marcus, J. \& J. Sabloff, 2008. The Ancient City: New perspectives on ancient urbanism. Santa Fe (NM): School for Advanced Research Press.

Masson, V., 1990. Tripolskoe obshtestvo i ego socialno-ekonomicheske harakteristiki [Trypillia society and its socio-economic characteristics], in Rannezemledelcheskie poselenie-giganti tripolskoi kulturi na Ukraine. Tezisi dokladov pervogo polevogo seminara [Early agricultural settlement-giants of the Trypillia culture in Ukraine. Proceedings of the first field seminar], ed. V. Zbenovich. Taljanki: Institut Arheologii AN USSR, 8-10.

McCorriston, J., 2011. Pilgrimage and Household in the Ancient Near East. Cambridge: Cambridge University Press.

Monah, D. \& F. Monah, 1997. The last great Chalcolithic civilization of Old Europe, in Cucuteni. The last great Chalcolithic civilization of Europe, eds. C.-M. Mantu, Gh. Dumitroaia \& A. Tsaravopoulos. Thessaloniki: Athena Printing House, 15-95.

Moore, T., 2017. Alternatives to urbanism? Reconsidering oppida and the urban question in Late Iron Age Europe. Journal of World Prehistory 30(3), 281-300.

Morris, I., 2005. The growth of Greek cities in the first millennium BC. SSRN Electronic Journal. 10.2139/ ssrn. 1426835

Müller, J., R. Hofmann \& S. Brandstätter, 2016a. Chronology and demography: how many people lived in a mega-site?, in Trypillia Megasites and European Prehistory 4100-3400 BCE, eds J. Müller, K. Rassmann \& M. Videiko. (Themes in Contemporary Archaeology 2.) Abingdon: Routledge, 133-70.

Müller, J., K. Rassmann \& M. Videiko (eds), 2016b. Trypillia Megasites and European Prehistory 4100-3400 BCE. (Themes in Contemporary Archaeology 2.) Abingdon: Routledge.

Nebbia, M., 2017. Early Cities or Large Villages? Settlement Dynamics in the Trypillia Group, Ukraine. Unpublished PhD thesis, Durham University.

Nebbia, M., B. Gaydarska, A. Millard \& J. Chapman, 2018. The making of Chalcolithic assembly places: Trypillia megasites as materialized consensus among equal strangers? World Archaeology 50(1), 41-61.

Ohlrau, R., M. Dal Corso, W. Kirleis \& J. Müller, 2016. Living on the edge? Carrying capacities of Trypillian settlements in the Buh-Dnipro interfluve, in Trypillia Megasites and European Prehistory 4100--3400 BCE, eds. J. Müller, K. Rassmann \& M. Videiko. (Themes in Contemporary Archaeology 2.) Abingdon: Routledge, 207-20. 
Parker Pearson, M., 2015. Stonehenge: Making sense of a prehistoric mystery. York: Council for British Archaeology.

Parkinson, W. \& M. Galaty, 2007. Secondary states in perspective: an integrated approach to state formation in the prehistoric Aegean. American Anthropologist 109, 113-29.

Pauketat, T. \& T. Emerson (eds), 2000. Cahokia: Domination and ideology in the Mississippian world. Lincoln (NEB): University of Nebraska Press.

Popovici, D.N., 2000. Cultura Cucuteni Faza A. Repertoriul aşezărilor (1) [Cucuteni culture Phase A. A gazetteer of settlements]. Piatra Neamţ: Centre de Recherches sur la civilisation Cucuteni.

Rassmann, K., A. Korvin-Piotrovsky, M. Videiko \& J. Müller, 2016. The new challenge for site plans and geophysics: revealing the settlement structure of giant settlements by means of geophysical survey, in Trypillia Megasites and European Prehistory 41003400 BCE, eds J. Müller, K. Rassmann \& M. Videiko. (Themes in Contemporary Archaeology 2). Abingdon: Routledge, 29-54.

Robinson, E.C. (ed.), 2014. Papers on Italian Urbanism in the First Millennium BC. (JRA Supplement 97.) Portsmouth (RI): Journal of Roman Archaeology.

Semple, S., 2018. Editorial: Temporary places, gatherings and assemblies. World Archaeology 50(1), 1-6.

Shmaglij, N., 2001 Veliki tripil'ski poseleniya i problema ranih form urbanizatsii [Large Trypillia settlements and the problem of early urbanisation]. Kiev: MP Tirazh.

Shukurov, A. \& M. Videiko, 2017. The evolving system of Trypillian settlements. https://arxiv.org/ftp/arxiv/ papers/1705/1705.03398.pdf

Shumilovskikh, L.S., E. Novenko \& T. Giesecke, 2017. Long-term dynamics of the east European foreststeppe ecotone. Journal of Vegetation Science. DOI: $10.1111 /$ jvs. 12585

Smith, M.E., 2007. Form and meaning in the earliest cities. A new approach to ancient urban planning. Journal of Planning History 6(1), 3-47.

Smith, M.E., 2016. How can archaeologists identify early cities: definitions, types, and attributes, in Eurasia at the Dawn of History. Urbanisation and social change, eds. M. Fernández-Götz \& D. Krausse. Cambridge: Cambridge University Press, 153-68.

Smith, M.L., 2003. Introduction, in The Social Construction of Ancient Cities, ed. M.L. Smith. Washington (DC): Smithsonian Institution Press, 1-36.

Smith, M.L., 2008. Urban empty spaces. Contentious places for consensus-building. Archaeological Dialogues 15(2), 216-31.

Videiko, M.Yu., 2013. Kompleksnoe Izuchenie Krupnykh Poselenij Tripolskoj Kultury $V-I V$ Tys Do N.e [Comprehensive investigations of the large settlements of the Trypillia culture - 5th-4th mill. BC]. Saarbrücken: Lambert Academic Publishing.
Wengrow, D., 2001. The evolution of simplicity: aesthetic labour and social change in the Neolithic Near East. World Archaeology 33(2), 168-88.

Wengrow, D., 2015. Cities Before the State in Early Eurasia. (Goody Lecture, Max Planck Institute for Social Anthropology, Department 'Resilience and Transformation in Eurasia'.)

Wengrow, D. \& D. Graeber, 2015. Farewell to the 'childhood of man': ritual, seasonality and the origins of inequality. Journal of the Royal Anthropological Institute 21, 597-619.

Wiessner, P., 1983. Style and social information in Kalahari San projectile points. American Antiquity 48(2), 253-76.

Wirth, L., 1938. Urbanism as a way of life. American Journal of Sociology 44, 1-24.

Yoffee, N. (ed.), 2015. The Cambridge World History. Volume 3: Early cities in comparative perspective, 4000 BCE1200 CE. Cambridge: Cambridge University Press.

Zbenovich, V., 1990. K probleme krupnih tripol'skih poselenii [About the problem of the large Trypillia settlements], in Rannezemledelcheskie poseleniya-giganty Tripolskoj kultury na Ukraine: Tez. dokl. I-go polevogo seminara [Early agricultural settlement-giants of the Trypillia culture in Ukraine. Proceedings of the first field seminar], ed. V. Zbenovich. Talianki: Institute of Archaeology of the Academy of Sciences of the USSR, 10-12.

Žižek, S., 2012. Less Than Nothing. Hegel and the shadow of dialectical materialism. London: Verso.

\section{Author biographies}

Bisserka Gaydarska is a specialist in Balkan prehistory, with her doctoral research a rescue landscape archaeological study of a mining area in Bulgaria. She has pursued post-doctoral research on artifact fragmentation, Ottoman mortuary monuments in Bulgaria, the Trypillia megasites project and Professor Whittle's 'The Times of Their Lives' project.

Marco Nebbia is a postdoctoral researcher at UCL Institute of Archaeology. He specialized in landscape and GIS applications in archaeology and the origins of prehistoric urbanism. His doctoral research focused on the Trypillia megasites of Ukraine. Currently he works with the ‘Central Asian Archaeological Landscapes' Project.

John Chapman is Emeritus Professor of European Prehistory at Durham University. He spent his career researching the Mesolithic, Neolithic and Chalcolithic of Eastern and Central Europe, directing major fieldwork projects in former Yugoslavia, Hungary and, most recently, Ukraine. With Gaydarska, he pioneered the study of deliberate fragmentation in archaeology. 